Hydrol. Earth Syst. Sci., 12, 1-19, 2008

www.hydrol-earth-syst-sci.net/12/1/2008/

(C) Author(s) 2008. This work is licensed

under a Creative Commons License.

\title{
A conceptual model of flow to the Waikoropupu Springs, NW Nelson, New Zealand, based on hydrometric and tracer $\left({ }^{18} \mathrm{O}, \mathrm{Cl},{ }^{3} \mathrm{H}\right.$ and $\mathrm{CFC}$ ) evidence
}

\author{
M. K. Stewart ${ }^{1, *}$ and J. T. Thomas ${ }^{2}$ \\ ${ }^{1}$ GNS Science, Lower Hutt, New Zealand \\ ${ }^{2}$ Tasman District Council, Richmond, New Zealand \\ * now at: Aquifer Dynamics Ltd, Lower Hutt, New Zealand
}

Received: 27 April 2007 - Published in Hydrol. Earth Syst. Sci. Discuss.: 31 May 2007

Revised: 12 October 2007 - Accepted: 7 December 2007 - Published: 18 January 2008

\begin{abstract}
The Waikoropupu Springs, a large karst resurgence $4 \mathrm{~km}$ from the coast, are supplied by the Arthur Marble Aquifer (AMA) underlying the Takaka Valley, South Island, New Zealand. New evidence on the recharge sources in the catchment, combined with previous results, is used to establish a new recharge model for the AMA. Combined with the oxygen-18 mass balance, this yields a quantitative description of the inputs and outputs to the aquifer. It shows that the Main Spring is sourced mainly from the karst uplands (74\%), with smaller contributions from the Upper Takaka River $(18 \%)$ and valley rainfall (8\%), while Fish Creek Spring contains mostly Upper Takaka River water (50\%). In addition, much of the Upper Takaka River contribution to the aquifer (58\%) bypasses the springs and is discharged offshore via submarine springs. The chemical concentrations of the Main Spring show input of $0.5 \%$ of sea water on average, which varies with flow and derives from the deep aquifer. Tritium measurements spanning $40 \mathrm{yr}$, and CFC- 11 measurements, give a mean residence time of $8 \mathrm{yr}$ for the Main Spring water using the preferred two-component model. Our conceptual flow model, based on the flow, chloride, oxygen-18 and age measurements, invokes two different flow systems with different recharge sources to explain the flow within the AMA. One system contains deeply penetrating old water with mean age $10.2 \mathrm{yr}$ and water volume $3 \mathrm{~km}^{3}$, recharged from the karst uplands. The other, at shallow levels below the valley floor, has much younger water with mean age $1.2 \mathrm{yr}$ and water volume $0.4 \mathrm{~km}^{3}$, recharged by Upper Takaka River and valley rainfall. The flow systems contribute in different proportions to the Main Spring, Fish Creek Springs and offshore springs. Their very different behaviours, despite being in the same
\end{abstract}

Correspondence to: M. K. Stewart

(mk.stewart@gns.cri.nz) aquifer, are attributed to the presence of a diorite intrusion below the surface of the lower valley, which diverts the deep flow towards the Waikoropupu Springs and allows much of the shallow flow to pass over the intrusive and escape via submarine springs.

\section{Introduction}

The Arthur Marble Aquifer (AMA) underlies the Takaka Valley on the South Island of New Zealand (Figs. 1, 2), and supplies the Waikoropupu Springs comprising the Main Spring, Dancing Sands Spring and Fish Creek Springs (Fig. 3). Waikoropupu Springs are locally known as Pupu Springs, and the latter term is used below for the collective discharges. The springs are New Zealand's largest and an impressive sight; their average flow is $13300 \mathrm{l} / \mathrm{s}$. They are karstic, tidal and slightly brackish $(\mathrm{Cl} \sim 100 \mathrm{mg} / \mathrm{l})$. The springs emerge from Arthur Marble through a cover of Motupipi Coal Measures approximately $4 \mathrm{~km}$ south of Golden Bay and 14$17 \mathrm{~m}$ a.s.l. The source of the water has been at issue since the end of the last century (Park, 1890).

The mystique of the springs has to do with their size, phenomenal clarity and attractive setting (Williams, 2007; Davies-Colley and Smith, 1995). But the springs have many other interesting features. Their sheer size suggests that they are drawn from a diversity of sources over a wide area in company with large karstic springs elsewhere in the world (Ford and Williams, 1989; Williams, 2004). The Pupu Springs are the main discharge zone of the AMA. Arthur Marble also outcrops east and west of the lower valley, and in the upper headwaters of the Waitui Stream (Fig. 1). Several investigations in the late 1970s established some

Published by Copernicus Publications on behalf of the European Geosciences Union. 

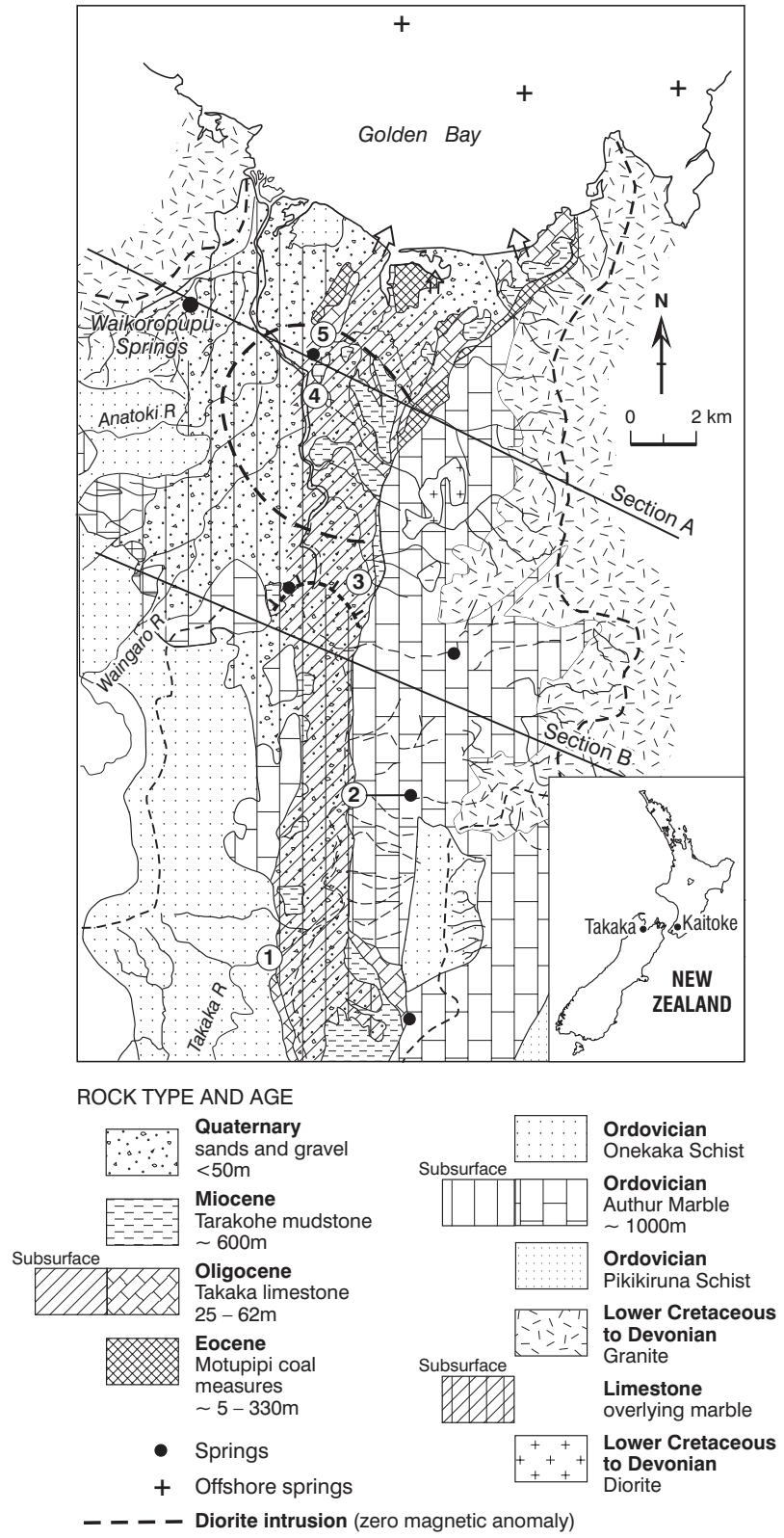

Fig. 1. Hydrogeological map of the Takaka Valley, NW Nelson, New Zealand (modified from Ford and Williams, 1989). Note the zero magnetic anomaly outline (inferred diorite intrusion).

physical, hydrological, and chemical features of the springs (Michaelis, 1976; Williams, 1977; Stewart and Williams, 1981; Stewart and Downes, 1981). Further work has been reported in the 1980s and 1990s (Mueller, 1987; Mueller, 1992; Edgar, 1998; Thomas, 2000; Taylor, 2001).

The Pupu Springs lie on the western side of the Takaka Valley (Fig. 1). Williams (1977) demonstrated hydraulic connection between Takaka River water sinking into its bed $16-18 \mathrm{~km}$ inland of the springs and the springs themselves by pulse-train analysis, using pulses in the Takaka River
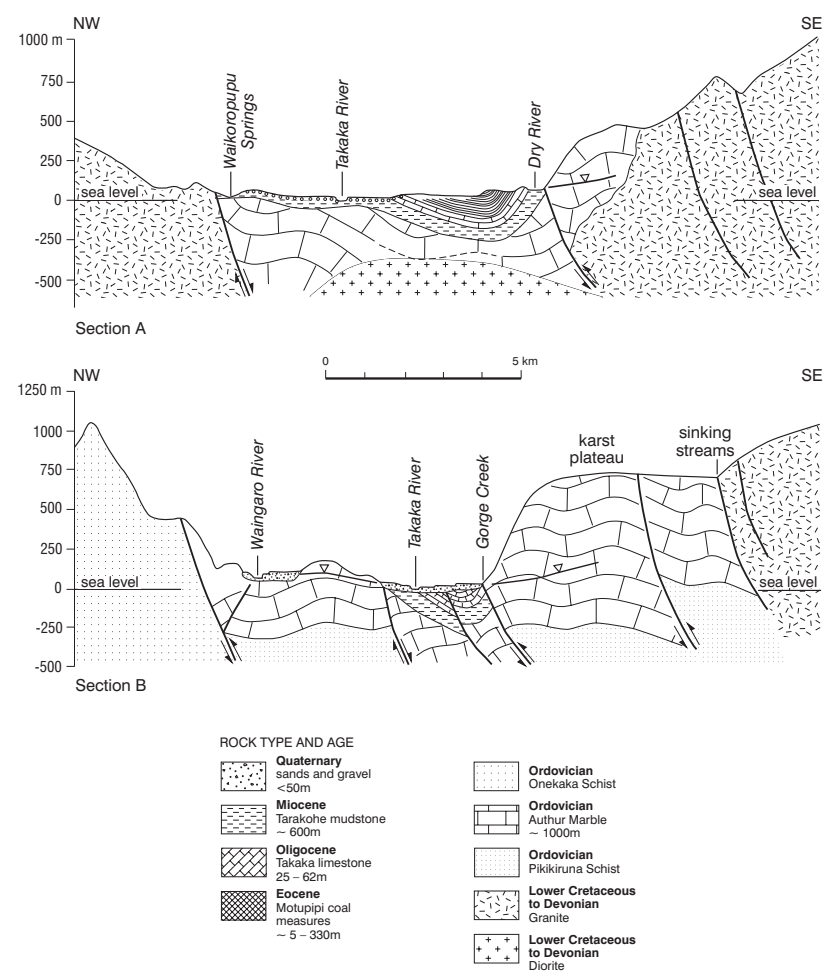

Fig. 2. Geological cross-sections of the Takaka Valley (modified from Ford and Williams, 1989).

flow caused by releases from the upstream Cobb Reservoir. This, however, does not prove flow connection (which tracing could show). He also discussed the location of the springs and the nature of the subterranean system.

This paper brings together existing and new evidence to improve our understanding of flow in the AMA, and in particular the sources of the Pupu Springs. Hydrometric information on the sources of recharge is critically evaluated and combined with the oxygen-18 mass balance to produce a quantitative recharge/discharge flow model for the AMA. Chloride concentrations of the Main Spring combined with oxygen-18 values point to a two-component flow system. Tritium, CFC and oxygen-18 measurements are used to determine water residence times. Because the tritium measurements on the Main Spring almost cover the rise and fall of tritium in the atmosphere due to nuclear weapons testing in the 1950 s and 1960 s, they are particularly reliable for determining the mean residence time and the shape of the age distribution.

The various types of evidence are used to produce a conceptual model of flow in the AMA involving two apparently almost independent flow systems. These combine in different proportions to produce the various outflows of the Pupu Springs, and offshore springs. 


\section{Hydrogeological setting}

The Takaka Valley is a wedge-shaped depression, $9 \mathrm{~km}$ across at its widest point on the coast, $26 \mathrm{~km}$ long, and oriented north-south (Rattenbury et al., 1998; Figs. 1, 2). Due to the eastward tilts of the blocks on each side of the valley, the catchment is strongly asymmetric with the major portion being in the Tasman Mountains on the western side. The Tasman Mountains are composed of Paleozoic schists. A faultscarp rising to a karstic plateau of Arthur Marble at $850 \mathrm{~m}$ forms the steep eastern wall of the valley. The karstic plateau butts against Paleozoic igneous intrusive rocks (granite and diorite) on the east. Paleozoic granite is also found northwest of Pupu. The schists and intrusives have extremely low porosity and permeability and are classed as aquifuges (Ford and Williams, 1989).

Much of the valley is covered with Quaternary sands and gravels above Tertiary sediments, including Tarakohe Mudstone, Takaka Limestone and Motupipi Coal Measures that are exposed in several places. Tarakohe Mudstone and Motupipi Coal Measures are aquicludes. The Tertiary sediments lie unconformably on Arthur Marble, which extends to the coast and is possibly intruded in the mid-valley area by diorite (as indicated in Figs. 1, 2). From the mid-valley to the lower valley, water in the marble, probably occupying gravelchoked solution cavities, is confined by the overlying lowpermeability coal measures. Tertiary sediments crop out in the mid-to-lower valley regions.

The Takaka River has a catchment area of $928 \mathrm{~km}^{2}$, and includes subcatchments of the Waingaro, Anatoki, Waikoropupu Rivers on the west (Fig. 1). Precipitation ranges from $1900-5000 \mathrm{~mm} / \mathrm{yr}$ between the lowest and highest altitudes. The Anatoki catchment $(5000 \mathrm{~mm} / \mathrm{yr})$ receives more precipitation per unit area than the Waingaro catchment $(3200 \mathrm{~mm} / \mathrm{yr})$, which in turn receives more than the Upper Takaka catchment $(2700 \mathrm{~mm} / \mathrm{yr})$. The decrease in precipitation from west to east is due to the westerly-dominated weather systems, which shed most rainfall on the first mountain ranges they encounter. Mountain range and peak altitudes are about the same in all three sub-catchments.

There are three main water-bearing geological units in the area; 1) the Arthur Marble Aquifer, 2) the Takaka Limestone Aquifer, and 3) the Takaka Valley Unconfined Gravel Aquifer. The hydrologic characteristics of these aquifers are directly related to their lithology/geology.

\subsection{Arthur Marble Aquifer (AMA)}

The AMA is the principal aquifer in the Takaka Valley area, developed in karstic Ordovician Arthur Marble. Arthur Marble is found underneath the Takaka Valley floor, from Upper Takaka to the Golden Bay coast, and in the mountain ranges parallel to this valley section (Fig. 1). Figure 2 shows northwest-southeast cross-sections (Sections A and

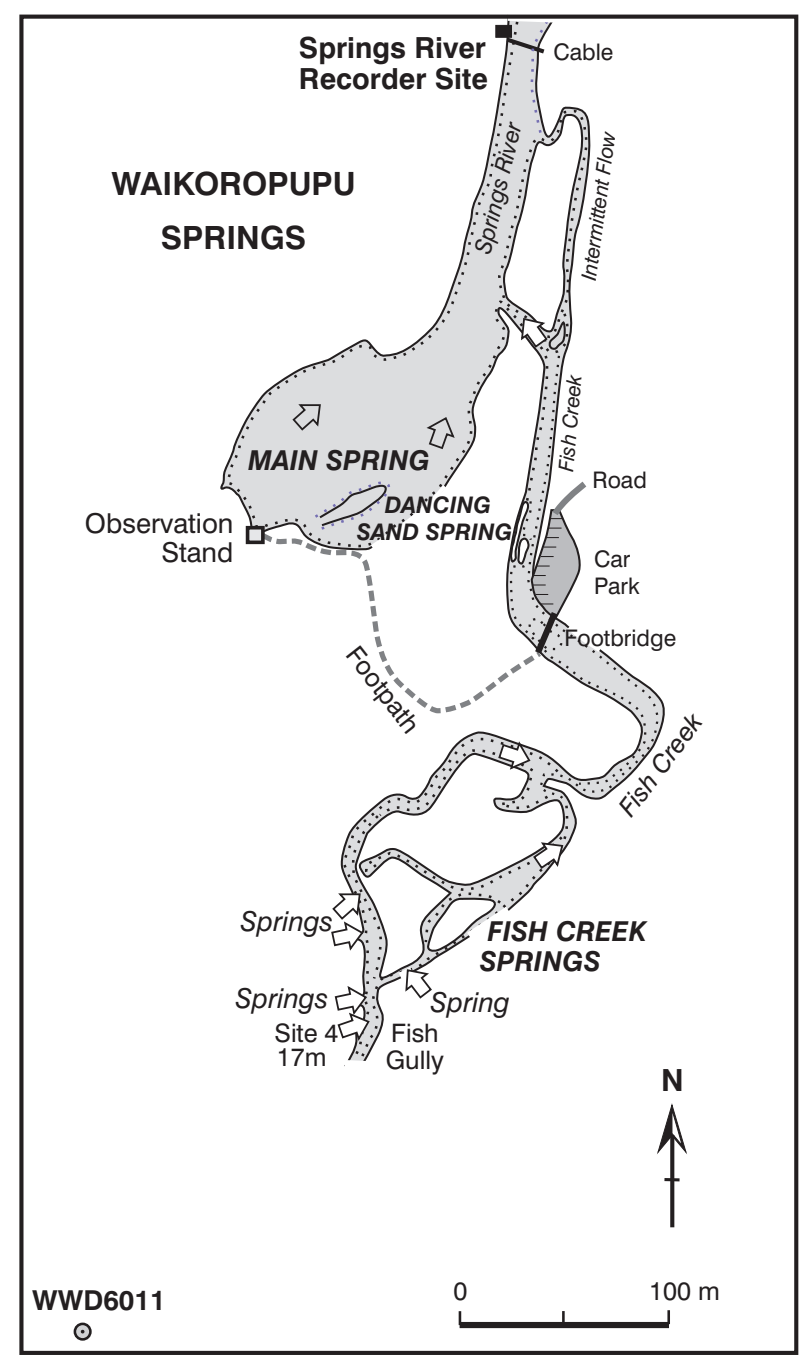

Fig. 3. Plan of the Pupu Springs, showing the locations of the springs and Balls bore (WWD6011) (from Rapier, 1975).

B). Marble covers an area of $180 \mathrm{~km}^{2}$ in the Central and Lower Takaka subcatchments.

The thickness of the marble is at least $500 \mathrm{~m}$ and possibly up to $1000 \mathrm{~m}$. Williams (2004) identifies primary, secondary and tertiary porosities of rock matrix, fissures and solution conduits in New Zealand carbonate rocks. Limestones usually have primary porosity less than $2 \%$, but marble (produced by metamorphosis of limestone) will have almost zero porosity. Nevertheless, Williams (2004) considers that the porous matrix and fissures combined will provide at least $98 \%$ of the water storage capacity of the Arthur Marble, because of the very massive bedding. And that the widelyspaced solution channels will transmit more than $95 \%$ of the groundwater flow.

Dissolution of the marble has caused the formation of a significant surface karstic landscape, with features such as karren, dolines, swallow holes, a strong serrated relief, 

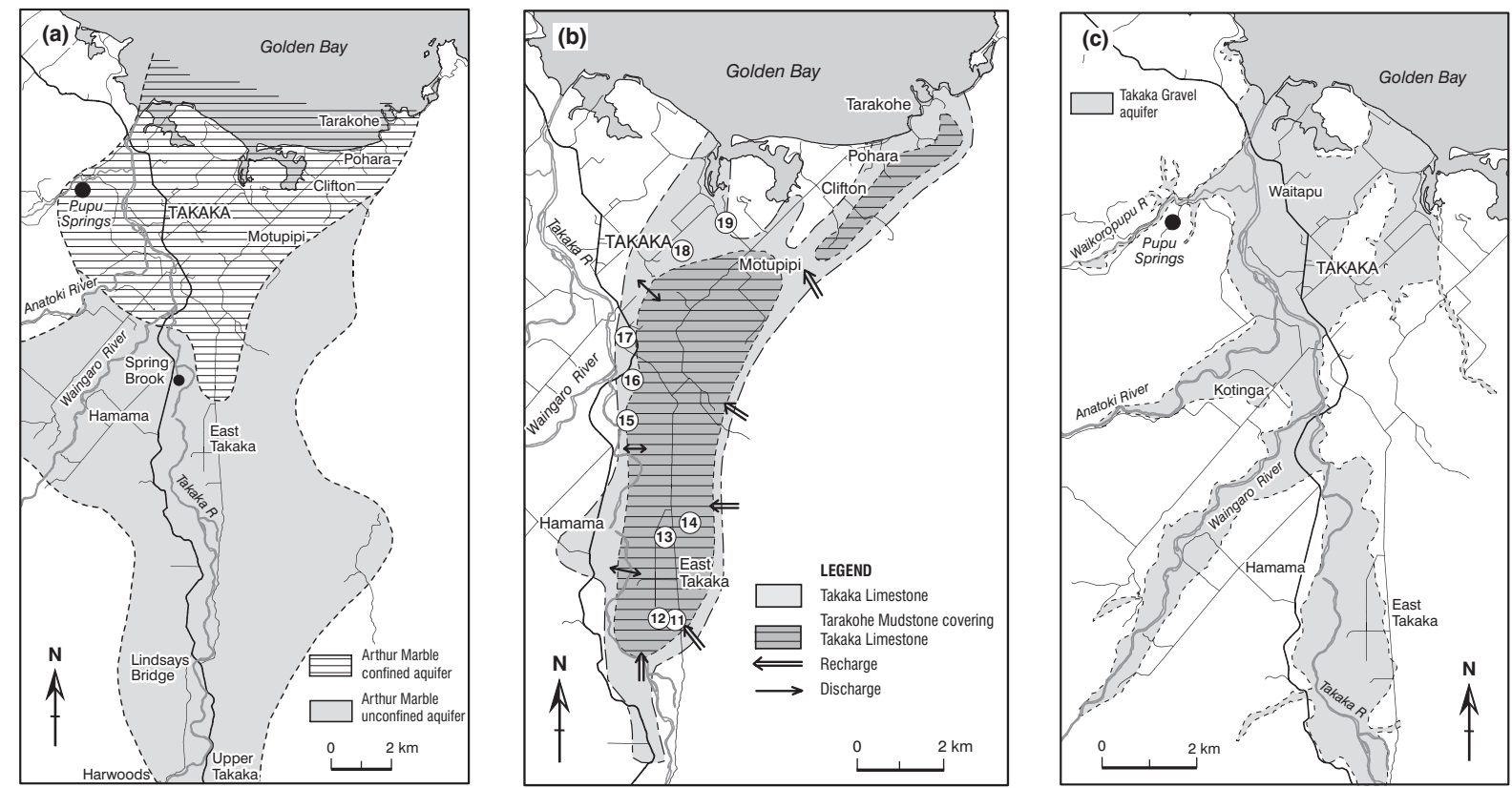

Fig. 4. Maps showing (a) Arthur Marble Aquifer, (b) Takaka Limestone Aquifer (showing sample locations 11-19), and (c) Takaka Gravel Aquifer.

and a significant subterranean aquifer system. The depth of karstification below the valley is unknown, but given sea level change (to $-130 \mathrm{~m}$ at the height of the last glaciation $17000 \mathrm{yr}$ ago) karstification to $1-200 \mathrm{~m}$ depth at least would be expected (Ford and Williams, 1989; Fleury et al., 2007).

Under the Central Takaka Valley floor the marble is covered $\left(45 \mathrm{~km}^{2}\right)$ by tens of metres of alluvial gravel, and in the Lower Takaka catchment it is additionally covered by Tertiary formations $\left(45 \mathrm{~km}^{2}\right)$ composed of Motupipi Coal Measures, Takaka Limestone and Tarakohe Mudstone.

The AMA is unconfined from Upper Takaka to about Hamama (Fig. 4a). In the unconfined area, Arthur Marble is overlain by cavernous Takaka Limestone and/or permeable alluvial gravels. The aquifer surface is defined by the water table, and the lithological boundary between marble and limestone has no distinguishable influence on groundwater flows. North of Hamama, impervious Motupipi Coal Measures overlie the Arthur Marble and the aquifer surface is defined by the elevation of the base of the Motupipi Coal Measures (Fig. 4a).

Recharge to the AMA was studied by Mueller (1992) and Edgar (1998). Their estimates from the various possible recharge sources are summarised in Table 1 in condensed form, and examined in light of later evidence in Sect. 4.1.

\subsection{Takaka Limestone Aquifer (TLA)}

The TLA occurs between East Takaka and Tarakohe (Fig. 4b) and is a result of karstification processes on Oligocene
Limestone. In the northern half of the Valley (north of Hamama and East Takaka), the TLA is underlain by the Motupipi Coal Measures, which act as an aquiclude. The aquiclude is absent south of Hamama and East Takaka, and the Arthur Marble and TLA are indistinguishable. Takaka Limestone is gently folded into a series of low amplitude synclines and anticlines. Only small amounts of groundwater are abstracted from this aquifer and the aquifer thickness varies between 30 and $60 \mathrm{~m}$ (Thomas, 2001).

Recharge to the aquifer is from rainfall, seepage from creeks draining the eastern boundary and inflow from the Upper Takaka River.

\subsection{Takaka Valley Unconfined Gravel Aquifer (TVUGA)}

Quaternary gravel and sand deposits cover most of the Takaka Valley from Upper Takaka to the sea (Fig. 4c). The major water-bearing gravels are the ones underlying the lowest river terraces of the Takaka Valley and Takaka Township. The thickness of the gravels varies down the valley. Around Lindsay's Bridge the gravels are about $10 \mathrm{~m}$ thick, whilst recent drilling upstream of East Takaka revealed a gravel thickness of $57 \mathrm{~m}$. The gravel is generally between 5-12 m thick in East Takaka. In the central part of Takaka Township, the gravels are estimated to be $30-40 \mathrm{~m}$ thick. 
Table 1. Recharge flows to the AMA.

\begin{tabular}{llll}
\hline Source of recharge & Mueller (1992) & Edgar (1998) (min.) & This work \\
\hline Karst uplands (1/s) & 10200 & 4500 & 9200 \\
Upper Takaka River (1/s) & 11000 & 8000 & 8350 \\
Valley rainfall (1/s) & 2200 & 2200 & 2200 \\
Total recharge (1/s) & 23400 & 14700 & 19750 \\
\hline
\end{tabular}

\section{Sampling and methods}

\subsection{Chemical data}

Water samples from rivers, springs, and groundwater wells have been collected by Tasman District Council hydrologists over a number of years. Groundwater wells were purged of at least three casing volumes before samples were taken (Rosen et al., 1999). Samples for cation analyses were field filtered and acidified with high-purity nitric acid. Anion samples were field filtered and kept below $4^{\circ} \mathrm{C}$ until analysed, and bicarbonate samples were collected unfiltered, kept below $4^{\circ} \mathrm{C}$, and analysed within $48 \mathrm{~h}$ of collection. Analytical methods have changed for some parameters, but in general the same methods have been used for each collection period. Methods for cation analyses include Atomic Adsorption and ICP-OES, and for anion analyses include auto-titrator, autoanalyser, and ion chromatography.

\subsection{Isotopic data}

Groundwater bores were purged of at least three casing volumes before samples were taken. Bottles were flushed with the water to be sampled, emptied, refilled with water and allowed to overflow. Care was taken to seal the bottles tightly to prevent sample evaporation. Samples of water were collected in $28 \mathrm{~mL}$ glass bottles for ${ }^{18} \mathrm{O}$, and $1.1 \mathrm{~L}$ bottles for tritium.

For ${ }^{18} \mathrm{O}$ measurement, $2 \mathrm{~mL}$ of the water is isotopically equilibrated with $\mathrm{CO}_{2}$ gas at $29^{\circ} \mathrm{C}$ for two hours, and then the $\mathrm{CO}_{2}$ is analysed in a stable isotope mass spectrometer (Hulston et al., 1981). Oxygen-18 concentrations are expressed as $\delta^{18} \mathrm{O}$ values, where

$$
\begin{aligned}
\delta^{18} \mathrm{O} \text { in per mille }= & {\left[\left({ }^{18} \mathrm{O} /{ }^{16} \mathrm{O}\right)_{\text {sample }} /\right.} \\
& \left.\left({ }^{18} \mathrm{O} /{ }^{16} \mathrm{O}\right)_{\text {VSMOW }}-1\right] \times 1000
\end{aligned}
$$

and VSMOW (Vienna Standard Mean Ocean Water) is the standard. The measurement precision is $\pm 0.1 \%$ o (standard error based on analysis of duplicate samples). Oxygen-18 concentrations in water are not affected by interaction with rock at ambient temperature, and therefore are ideal for identifying recharge sources provided there is sufficient contrast in the oxygen-18 concentrations of the possible source waters (Stewart and Taylor, 1981).
For tritium measurement, samples are distilled, enriched in tritium by a factor of 70 by electrolysis and then counted in a Quantulus 1220 ultra-low background Liquid Scintillation Counter for several weeks (Taylor, 1994; Morgenstern and Taylor, 2005). Measurement precision was greatly improved in the 1980s and 90s by methods which have been extensively documented (Taylor, 1994; IAEA, 1995 and Morgenstern and Taylor, 2005). Measurement errors $(1 \sigma)$ on samples at the current ambient tritium level are $\pm 2.8 \%$ (about $\pm 0.04 \mathrm{TU})$.

\subsection{Chlorofluorocarbons}

Water samples for ambient CFC concentration measurements were collected in such a way as to prevent contact of the sample with the atmosphere or with plastic materials, either of which could contaminate the water with excess CFCs. The samples were preserved in the field by sealing them into $62 \mathrm{~mL}$ borosilicate glass ampoules at the spring or bore site (Vanessa Fox (GNS Science), pers. comm.; Busenberg and Plummer, 1992). Where possible, the sampling apparatus was connected to the bore outlet by copper tubing. All other tubing in contact with the water during sampling was stainless steel. The ampoule was attached to the sampling apparatus and flushed with UHP nitrogen gas (99.999\% purity, with listed gases less than specified amounts). The well water was then allowed to flow through the tubing and valves and into the bottom of the ampoule, displacing the nitrogen. The ampoule was rinsed with several hundred millilitres of water, then nitrogen was forced into the neck to displace some of the water. The ampoule was then fused shut about $1-2 \mathrm{~cm}$ above the water level with an oxy/acetylene gas torch. $\mathrm{Ni}$ trogen flowed continually across the union to prevent any air contamination. Four ampoules were normally collected at each sampling site. The CFC samples were analysed by gas chromatography using an ECD detector.

\subsection{Residence time determination}

The different flow paths of water through the groundwater system mean that outflows contain water with a variety of residence times. This distribution of ages may be described by a conceptual flow model, which reflects the average conditions of flow in the system. 
Table 2. Mean annual $\delta^{18} \mathrm{O}$ values of waters from the Takaka Valley.

\begin{tabular}{|c|c|c|c|c|c|c|}
\hline \multirow{2}{*}{$\begin{array}{l}\text { Map } \\
\text { ID }\end{array}$} & \multirow{2}{*}{$\begin{array}{l}\text { Feature } \\
\text { Sampled }\end{array}$} & \multicolumn{5}{|c|}{$\delta^{18} \mathrm{O}(\% o)$} \\
\hline & & 1976 & 1977 & 1978 & 1979 & Mean \\
\hline 1 & Upper Takaka River & -8.73 & -8.75 & -8.66 & -8.53 & -8.67 \\
\hline 2 & Ironstone Creek & -7.68 & -7.85 & -7.88 & -7.66 & -7.77 \\
\hline 3 & Lows bore & -7.88 & -7.97 & -7.99 & -7.93 & -7.94 \\
\hline 4 & CTWB & -6.15 & -6.24 & -6.32 & -6.26 & -6.24 \\
\hline 5 & Dairy Co. bore & -8.13 & -8.28 & -8.33 & -8.16 & -8.23 \\
\hline 6 & Pupu Main Spring & -7.24 & -7.31 & -7.48 & -7.50 & -7.38 \\
\hline 7 & Pupu Fish Spring & -7.53 & -7.67 & -7.69 & -7.66 & -7.64 \\
\hline \multirow[t]{3}{*}{8} & Rainfall (mean) & -5.41 & -5.43 & -5.27 & -5.50 & -5.40 \\
\hline & Rainfall (weighted) & -5.62 & -5.98 & -6.10 & -5.59 & -5.82 \\
\hline & Rainfall amount (mm) & 2730 & 2178 & 2037 & & \\
\hline
\end{tabular}

Rainfall incident on a catchment can be affected by surface/near surface runoff and evapotranspiration losses. The remainder constitutes effective recharge to the subsurface water stores. The tracer inputs (tritium and CFC concentrations, temporal ${ }^{18} \mathrm{O}$ variations in the recharge water) are modified by passing through the hydrological system (as represented by the flow model) before appearing in the output. The convolution integral and an appropriate flow model are used to relate the tracer input and output (Maloszewski and Zuber, 1982). The convolution integral is given by

$\mathrm{C}_{\text {out }}(t)=\int_{o}^{\infty} \mathrm{C}_{\text {in }}(t-\tau) h(\tau) \exp (-\lambda \tau) d \tau$

where $\mathrm{C}_{\text {in }}$ and $\mathrm{C}_{\text {out }}$ are the input and output concentrations in the recharge and outflow, respectively. $\mathrm{t}$ is calendar time and the integration is carried out over the transit times $\tau$. $h(\tau)$ is the flow model or transit time distribution function of the hydrological system. The exponential term accounts for radioactive decay of tritium ( $\lambda$ is the tritium decay constant ( $=\ln 2 / \mathrm{T}_{1 / 2}$, where $\mathrm{T}_{1 / 2}$ is the half-life of tritium (12.32 yr)).

Karst aquifers have special qualities, in particular they are often described as dual porosity media, with fissuredporous matrix porosity and solution channel porosity (Ford and Williams, 1989). Maloszewski et al. (2002) noted that in such systems it is not possible to determine the mean residence time of water, but instead the mean residence time of tracer is determined, and that the dispersion model (see below) is the most suitable. Marble is recrystallised limestone, hence the primary matrix porosity will have been reduced during metamorphism.

Two flow models are commonly used in tracer studies. The exponential-piston flow model (EPM) combines a volume with exponential transit times (the recharge zone) followed by a piston flow volume (in the aquifer) to give a model with two parameters (Maloszewski and Zuber, 1982). The transit time distribution function is given by

$$
\begin{aligned}
h(\tau)= & \text { for } \quad \tau<\tau_{m}(1-f) \\
h(\tau)= & \left(f \tau_{m}\right)^{-1} \cdot \exp \left[-\left(\tau / f \tau_{m}\right)+(1 / f)-1\right] \\
& \text { for } \tau \geq \tau_{m}(1-f)
\end{aligned}
$$

where $\tau_{m}$ is the mean residence time (MRT), and $f$ the ratio of the exponential volume to the total volume. (Maloszewski and Zuber (1982) used the parameter $\eta ; f=1 / \eta$.)

The dispersion model (DM) assumes a tracer transport which is controlled by advective and dispersive processes (Maloszewski and Zuber, 1982),

$h(\tau)=\frac{1}{\tau \sqrt{4 \pi \mathrm{DP}\left(\tau / \tau_{m}\right)}} \exp \left[-\frac{\left(1-\tau / \tau_{m}\right)^{2}}{4 \mathrm{DP}\left(\tau / \tau_{m}\right)}\right]$

where DP is the dispersion parameter (defined as the mass of the variance of the dispersive distribution of the transit time). It includes not only variance in the aquifer (resulting from dispersive-convective transport), but also space variance resulting from the recharge distribution at the catchment surface and/or diffusive exchange of tracer with stagnant water in the aquifer. The parameters are $\tau_{m}$ and DP.

Models can be combined to represent more complicated systems, as illustrated by the EPM model above. Based on the understanding of the system gained from the flow, ${ }^{18} \mathrm{O}$, chemical and age dating measurements, we have used a model comprising two DM models in parallel; a "double dispersion" model (DDM). The two DMs describe shortresidence-time (shallow) and long-residence-time (deep) flow components or systems. The DDM model is simply formed by adding the two DM models:

$\mathrm{DDM}=b \mathrm{DM}_{s}+(1-b) \mathrm{DM}_{d}$

where $b$ is the fraction of the young component (shallow system fraction). The model has five parameters $\left(b, \tau_{m s}, \mathrm{DP}_{s}\right.$, $\left.\tau_{m d}, \mathrm{DP}_{d}\right)$.

\section{Results}

\subsection{Recharge sources to the AMA}

Recharge to the AMA can occur where Arthur Marble crops out at the surface or is covered by permeable rock such as Takaka Limestone or Quaternary gravels. Possible recharge sources are diverse and include drainage from rivers into sinks as concentrated point or linear inputs and infiltration of precipitation on karst or permeable cover as diffuse inputs.

Three groups of recharge sources have been identified as follows:

- Karst uplands on east and west of the valley (fed by sinks in tributary streams in Central Takaka, including the Waingaro and Anatoki Rivers, and rainfall)

- Upper Takaka River sinks

- Valley rainfall on the Central Takaka Valley

Mueller (1992) considered essentially the same groups of sources, except he separated the Waingaro and Anatoki Rivers from the karst uplands. Edgar (1998) added a fifth 
Table 3. Miscellaneous $\delta^{18} \mathrm{O}$ values of groundwaters from the Takaka Valley.

\begin{tabular}{|c|c|c|c|c|c|}
\hline \multirow{2}{*}{$\begin{array}{l}\text { Well } \\
\text { No. }\end{array}$} & \multirow{2}{*}{ 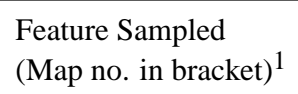 } & \multirow[t]{2}{*}{ Aquifer } & \multicolumn{3}{|c|}{$\delta^{18} \mathrm{O}(\%)$} \\
\hline & & & March 1999 & Feb 2000 & Mean \\
\hline & \multicolumn{2}{|c|}{ Karst uplands-sourced groundwater } & & & \\
\hline 6814 & Mansons bore (11) & Takaka Limestone & -6.91 & -6.86 & \\
\hline 6821 & Borlase bore (12) & Takaka Limestone & & -7.09 & \\
\hline 6819 & Sixtus bore (13) & Takaka Gravel & -6.50 & -7.13 & \\
\hline \multirow[t]{2}{*}{6808} & Moyle bore (14) & Takaka Limestone & -6.97 & -6.74 & $-6.9 \pm 0.2$ \\
\hline & \multicolumn{2}{|c|}{ Valley rainfall-sourced groundwater } & & & \\
\hline S & Spring at quarry $(15)$ & Takaka Limestone & -5.46 & & \\
\hline 6604 & Bore at quarry (16) & Takaka Limestone & -5.75 & & \\
\hline 6601 & CTWB (17) & Takaka Limestone & -5.56 & & \\
\hline 6323/P5 & Bore Dairy Co. (18) & Takaka Limestone & -5.91 & & \\
\hline 6103 & Bisley bore (19) & Takaka Gravel & -5.83 & & $-5.7 \pm 0.2$ \\
\hline
\end{tabular}

${ }^{1}$ See Fig. 4b.

source being inter-aquifer leakage from the TLA, but did not estimate the amount of water being contributed from this source. We consider any such leakage to be included as part of the rainfall on the Central Takaka Valley.

Recharge from sinking streams in the karst uplands is an important source of water to the underlying aquifers. Fifteen named creeks and other unnamed subcatchments in the Central Takaka Valley (Figs. 1,4a) generally run dry in their lower reaches. They drain an area of about $170 \mathrm{~km}^{2}$. Average precipitation is about $2600 \mathrm{~mm} / \mathrm{yr}$, with evapotranspiration of $700 \mathrm{~mm} / \mathrm{yr}$, giving net precipitation of $1900 \mathrm{~mm} / \mathrm{yr}$ (Mueller, 1992). The uppermost parts of the subcatchments are on impervious bedrock (granite, schist) and flows are on the surface. The creeks then cross onto marble and the flows disappear through the gravel creek beds into cavernous marble. Most of the flows from tributary catchments recharge the AMA and only peak flows reach the Takaka River. Mueller (1992) estimated that $80 \%$ of the total flow in the karst uplands recharges the AMA contributing $8200 \mathrm{l} / \mathrm{s}$ on average. Edgar (1998, Chapter 3) estimated that recharge was 50\% from a $100 \mathrm{~km}^{2}$ area yielding their minimum estimate of $30001 / \mathrm{s}$ recharge. (They excluded the west bank tributaries.) We estimate recharge is $7200 \mathrm{l} / \mathrm{s}$ based on recharge of $70 \%$ on $170 \mathrm{~km}^{2}$.

The Waingaro and Anatoki Rivers cross marble in their middle reaches. Mueller (1992) estimated the loss from the Waingaro River to be 20001/s. Edgar's (1998, Chapter 3) estimate was $1500 \mathrm{l} / \mathrm{s}$. Our estimate is $2000 \mathrm{l} / \mathrm{s}$. All workers have considered the contribution from Anatoki River to be insignificant.

The Takaka River commonly runs dry in its reach below Lindsays Bridge (on about 100 d per year, Mueller, 1992) and is an obvious source of recharge to the AMA, as well as to the overlying limestone and gravel aquifers in contact with the AMA (see place names in Fig. 4). Most of the Takaka Valley from Upper Takaka to the sea is covered with a layer of river gravels. Underneath the gravel, Arthur Marble extends to a depth of several hundred metres below the valley floor. Between the Harwoods gauging station (near Upper Takaka) and the Spring Brook confluence, the river flows over the unconfined part of the AMA and recharges the aquifer through gravel covered sinks. Mueller (1992) estimated the average loss from the river to be 11000 l/s for the reach between Harwoods and Spring Brook confluence. Edgar (1998, Chapter 3 ) reduced the estimate to $8000-90001 / \mathrm{s}$. A re-examination of the Takaka River gauging data (P. White, pers. comm., 2001) has shown that the Harwoods to Lindsays Bridge reach loses 7501/s and the Lindsays Bridge to Spring Brook confluence reach loses $7600 \mathrm{l} / \mathrm{s}$ on average, giving total recharge to the underlying aquifers of $8350 \mathrm{l} / \mathrm{s}$.

Recharge from rainfall on the Takaka Valley floor occurs between Upper Takaka and Hamama (an area of about $73 \mathrm{~km}^{2}$ ). Major areas of recharge are the higher river terraces west of the Takaka River, and solution dolines or sinkholes are common in the area. Mueller (1992) estimated that 50\% of this rainfall recharges the AMA giving 22001/s. Edgar's (1998, Chapter 3) estimate was 2200-40001/s, but some of this was for precipitation on the karst plateau (east of the Takaka Valley, see Section B in Fig. 2), which is included in the karst uplands contribution in Mueller's and our models. Our estimate is $22001 / \mathrm{s}$.

Table 1 summarises Mueller's, Edgar's and our estimates of recharge to the AMA. Total recharge was $234001 / \mathrm{s}$ in the Mueller model, of which he considered that $150001 / \mathrm{s}$ was discharged by the Pupu Springs, and $84001 /$ s by submarine springs in Golden Bay. Recharge was 14700-200001/s in the Edgar (Chapter 3) model; the lower limit (given in the table) suggests that there are no submarine springs (Doyle and Edgar, 1998). Our estimate gives recharge of $197501 / \mathrm{s}$, and requires that there be submarine springs to account for the excess of recharge over discharge. 
Table 4. $\delta^{18} \mathrm{O}$ values of flows to and from the AMA. The contributions from individual recharge sources to each spring were adjusted to satisfy the oxygen-18 mass balance (based on the bolded measured quantities).

\begin{tabular}{|c|c|c|c|c|c|c|c|}
\hline \multirow{3}{*}{ Recharge source } & \multirow{3}{*}{$\begin{array}{l}\delta^{18} \mathrm{O} \\
\% o\end{array}$} & \multirow{2}{*}{$\begin{array}{r}\text { Mueller } \\
(1992)\end{array}$} & \multirow{2}{*}{$\begin{array}{r}\text { Edgar } \\
(1998)\end{array}$} & \multicolumn{3}{|c|}{ Flows in this work } & \multirow{3}{*}{$\begin{array}{r}\text { Total } \\
\text { Flows } \\
1 / \mathrm{s}\end{array}$} \\
\hline & & & & Main Spring & Fish Spring & Remainder & \\
\hline & & $1 / \mathrm{s}$ & $1 / \mathrm{s}$ & $1 / \mathrm{s}$ & $1 / \mathrm{s}$ & $1 / \mathrm{s}$ & \\
\hline Karst uplands & -7.20 & 10200 & 4500 & 7400 & 830 & 970 & 9200 \\
\hline Upper Takaka River & -8.67 & 11000 & 8000 & 1850 & 1650 & 4850 & 8350 \\
\hline Valley rainfall & -6.00 & 2200 & 2200 & 750 & 820 & 630 & 2200 \\
\hline Total flows (1/s) & & 23400 & 14700 & 10000 & 3300 & 6450 & 19750 \\
\hline$\delta^{18} \mathrm{O}^{1}(\% \circ)$ & & -7.78 & -7.82 & -7.38 & -7.64 & -8.19 & -7.69 \\
\hline Shallow fraction ${ }^{2}(b)$ & & - & - & 0.26 & 0.75 & 0.85 & - \\
\hline
\end{tabular}

${ }^{1}$ Weighted mean $\delta^{18} \mathrm{O}$ values of spring flows. See Eq. (6).

${ }^{2}$ See Eq. (5) for definition of $b$.

Known discharges from the AMA are mainly via the Pupu Springs. Mean discharge from the Main Spring complex was $10000 \mathrm{l} / \mathrm{s}$, with minimum and maximum flows of 7312 and 12459l/s between 1990 and 1997 (Edgar, 1998). Mean flow from the Fish Creek Springs was $33001 /$ s, with minimum and maximum flows of 53 and $6961 \mathrm{l} / \mathrm{s}$. Other much smaller springs are known in the Takaka Valley (shown by small black dots in Fig. 1), of which Spring Brook is the most significant. (Spring Brook comprises a stream as well as seepages, whose flows have not been measured independently of the stream.) Three submarine springs are known to exist in Golden Bay, but their flows have not been measured (Williams, 2004).

\subsection{Constraints on recharge sources: oxygen isotopes}

The average $\delta^{18} \mathrm{O}$ values of the three recharge sources are estimated from available data. Samples were collected at monthly intervals for three and a half years from eight locations in the Takaka Valley (Stewart and Williams, 1981; Table 2). This is long enough to give reasonable characteristic averages for the $\delta^{18} \mathrm{O}$ values of these features. Sampling sites (given in Fig. 1) were as follows:

1. Upper Takaka River, sampled at Harwoods gauging station.

2. Ironstone Creek (a spring-sourced perennial Takaka River tributary from the karst uplands on the east side of the valley).

3. Low's bore (groundwater from Arthur Marble in the Central Valley region, where the Takaka River loses much of its flow).

4. CTWB, previously known as Hodgkinson's bore (groundwater from the TLA).
5. Dairy Co. bore (groundwater from the Quaternary gravel aquifer (TTG) in the Lower Valley),

6. Pupu Main Spring.

7. Fish Spring (one of the Fish Creek Springs).

8. Bulk monthly rainfall samples from a rainfall collector sited at the Pupu Springs.

The Upper Takaka River (1.) was sampled before any losses had occurred to the underlying aquifers. The annual mean $\delta^{18} \mathrm{O}$ value was quite consistent from year to year and averaged $-8.67 \%$. The Upper Takaka River has the lowest $\delta^{18} \mathrm{O}$ value of any of the rivers studied. This results from rainout of the westerly-dominated weather systems causing the $\delta^{18} \mathrm{O}$ values to become progressively more negative from west to east (e.g. from the Anatoki $(-6.5 \%$ ), to the Waingaro $(-7.2 \%$ ) , to the Upper Takaka $(-8.7 \%$ ) catchments). The mean $\delta^{18} \mathrm{O}$ of recharge from the river should be close to that of the river itself, because the recharge travels via concentrated inputs (gravel covered sinks) into the aquifer and its amount is independent of river flow when the river does not run dry. Weighting the $\delta^{18} \mathrm{O}$ values with the river losses to the underlying aquifer gives a weighted mean $\delta^{18} \mathrm{O}$ of $-8.65 \%$, in agreement with the average value. The average $\delta^{18} \mathrm{O}$ for Upper Takaka River recharge is taken to be $-8.67 \%$ (Table 4).

The spring-fed Ironstone Creek (2.) has a perennial flow unlike most of the other karst upland streams from east and west of the valley. The average $\delta^{18} \mathrm{O}$ value is $-7.77 \%$. Low's bore (3.) penetrates Arthur Marble in the mid-valley region east of the Takaka River (Fig. 1). Its annual average $\delta^{18} \mathrm{O}$ value is $-7.94 \%$, and reflects karst upland and Upper Takaka River input. Other miscellaneous bore samples from East Takaka (samples 11-14, Table 3 and Fig. 4b) are sourced from east of the valley and had values near $-6.9 \%$. Samples 
Table 5. Chemical concentrations (mg/l) in some Takaka waters (14 March 1979).

\begin{tabular}{rrrrrrrrrr}
\hline ID & Sample & $\mathrm{Ca}$ & $\mathrm{HCO}_{3}$ & $\mathrm{Sr}$ & $\mathrm{Na}$ & $\mathrm{K}$ & $\mathrm{Mg}$ & $\mathrm{Cl}$ & $\mathrm{SO}_{4}$ \\
\hline 1 & Upper Takaka River & 10 & 37 & 0.04 & 2 & 0.2 & 2.4 & 2.6 & 3 \\
2 & Ironstone Creek & 47 & 157 & 0.11 & 4 & 0.5 & 1.3 & 2.1 & 1 \\
3 & Low's Bore & 43 & 139 & 0.09 & 3 & 0.5 & 2.4 & 3.3 & 4 \\
4 & CTWB & 42 & 135 & 0.12 & 6 & 0.5 & 2.7 & 5.6 & 3 \\
5 & Dairy Co. Bore & 14 & 48 & 0.05 & 3 & 0.3 & 2.1 & 3.2 & 3 \\
6 & Pupu Main Spring & 57 & 194 & 0.16 & 47 & 3.9 & 6.6 & 75 & 15 \\
7 & Pupu Fish Spring & 43 & 145 & 0.11 & 12 & 1.5 & 3.4 & 16 & 6 \\
\hline
\end{tabular}

from streams west of the valley were also close to $-7.0 \%$. On the basis of available data, the eastern tributaries have been assigned a mean $\delta^{18} \mathrm{O}$ of $-7.4 \%$ and the western tributaries $-7.0 \%$, making the overall mean $-7.2 \%$. The Waingaro and Anatoki Rivers have mean values of $-7.2 \%$ and $-6.5 \%$, respectively. Recharge from the karst upland tributary streams is mainly via concentrated inputs (gravel covered sinkholes), and the excess during the largest flows is shed when the waters reach the Takaka River. The average $\delta^{18} \mathrm{O}$ for karst uplands recharge is taken to be $-7.2 \%$ (Table 4).

The CTWB (4.), which draws water from Takaka Limestone, has an average $\delta^{18} \mathrm{O}$ value of $-6.24 \%$, showing that it is sourced almost entirely from valley rainfall. Samples from bores which draw on valley rainfall-recharged groundwater (samples 15-19, Table 3 and Fig. 4b) had an average $\delta^{18} \mathrm{O}$ of $-5.7 \%$. Bulk monthly rainfall (8.) was collected at a raingauge at the Pupu Springs. Rainfall amounts are high, being 2000-3000 mm per yr. The amount-weighted mean annual $\delta^{18} \mathrm{O}$ value is $-5.82 \%$. Evapotranspiration will cause preferential selection of winter rainfall leading to a more negative average $\delta^{18} \mathrm{O}$ value; the corrected $\delta^{18} \mathrm{O}$ is $-6.09 \%$. Recharge from rainfall on the Central Takaka Valley is via diffuse and concentrated (sinkhole) pathways. The average $\delta^{18} \mathrm{O}$ for valley rainfall recharge is taken to be $-6.0 \%$ (Table 4 ).

In the Lower Valley, the Dairy Co. bore (5.) has quite negative $\delta^{18} \mathrm{O}(-8.23 \%$ ) like the Takaka River. Both its hydrogeological situation and $\delta^{18} \mathrm{O}$ value suggest that the gravel aquifer here gains water from the Takaka River. However, in this reach the Takaka River has a large contribution from the Waingaro River (with mean $\delta^{18} \mathrm{O}$ of $-7.2 \%$ ), because so much of the Takaka flow is lost to sinks in its riverbed upstream of this point.

Samples were collected each month from both the Pupu Main Spring (6.) and Fish Spring (7.). A consistent difference in $\delta^{18} \mathrm{O}$ is found between them, with the Main Spring having higher (i.e. less negative) $\delta^{18} \mathrm{O}$. The annual mean values are $-7.38 \%$ and $-7.64 \%$, respectively (Table 2). A Student's t-test of the monthly values shows that the probability of these not being different is $0.0 \%(t=-13.5)$, i.e. there is $100 \%$ certainty that they are different. This means that the
Main Spring and Fish Spring waters contain different proportions of the source waters, and in particular Fish Spring contains more Upper Takaka River water than the Main Spring. The different proportions of the source waters in each spring are also reflected in their different chemical compositions and transit times, as seen below.

When the Pupu Springs outflow decreases and the Fish Creek Springs nearly cease to flow because of dry conditions, the $\delta^{18} \mathrm{O}$ and chemical composition of the Main Spring water become more like those of Fish Spring (Stewart and Downes, 1981). This shows that at such times the Main Spring draws on similar sources to Fish Spring, and suggests that the AMA is stratified.

The mean $\delta^{18} \mathrm{O}$ values of the inputs and outputs to the Arthur Marble system given above allow the mass balance of ${ }^{18} \mathrm{O}$ to be calculated (Table 4). The Mueller and Edgar recharge models give flow-weighted mean $\delta^{18} \mathrm{O}$ values of $-7.78 \%$ and $-7.82 \%$, respectively, for the springs' outflow (Table 4). These do not agree with the measured values for either the Main Spring $(-7.38 \%$ ) or Fish Spring $(-7.64 \%$ ) and therefore show that the models are not adequate to explain the data.

In our more complex model, the flows from each recharge source to each spring have been adjusted by means of a spreadsheet, so that the predicted $\delta^{18} \mathrm{O}$ values of the Main Spring and Fish Spring in Table 4 match the observed values. In effect, the bolded quantities in Table 4 are constraints that have to be met by a satisfactory model. The spreadsheet sums the flows horizontally and vertically, and calculates the weighted $\delta^{18} \mathrm{O}$ values for the springs; e.g. the weighted $\delta^{18} \mathrm{O}$ value for the Main Spring $\left(\delta_{\mathrm{MS}}\right)$ is given by

$\delta_{\mathrm{MS}}=\left(Q_{\mathrm{kuMS}} \delta_{\mathrm{ku}}+Q_{\mathrm{UTRMS}} \delta_{\mathrm{UTR}}+Q_{\mathrm{rfMS}} \delta_{\mathrm{rf}}\right) / Q_{\mathrm{MS}}$,

where $Q_{\mathrm{kuMS}}, Q_{\mathrm{UTRMS}}$, and $Q_{\mathrm{rfMS}}$ are the recharge flows to the Main Spring from the karstic uplands, the Upper Takaka River and the valley rainfall, respectively. $\delta_{\mathrm{ku}}, \delta_{\mathrm{UTR}}$ and $\delta_{\mathrm{rf}}$ are the $\delta^{18} \mathrm{O}$ values of the recharge sources.

It is found that neither the flows nor the mean $\delta^{18} \mathrm{O}$ values of the Main and Fish Springs can be matched if they are the only major outflows from the AMA system. An extra outflow of $64501 / \mathrm{s}$, with a $\delta^{18} \mathrm{O}$ value of $-8.19 \%$, is 

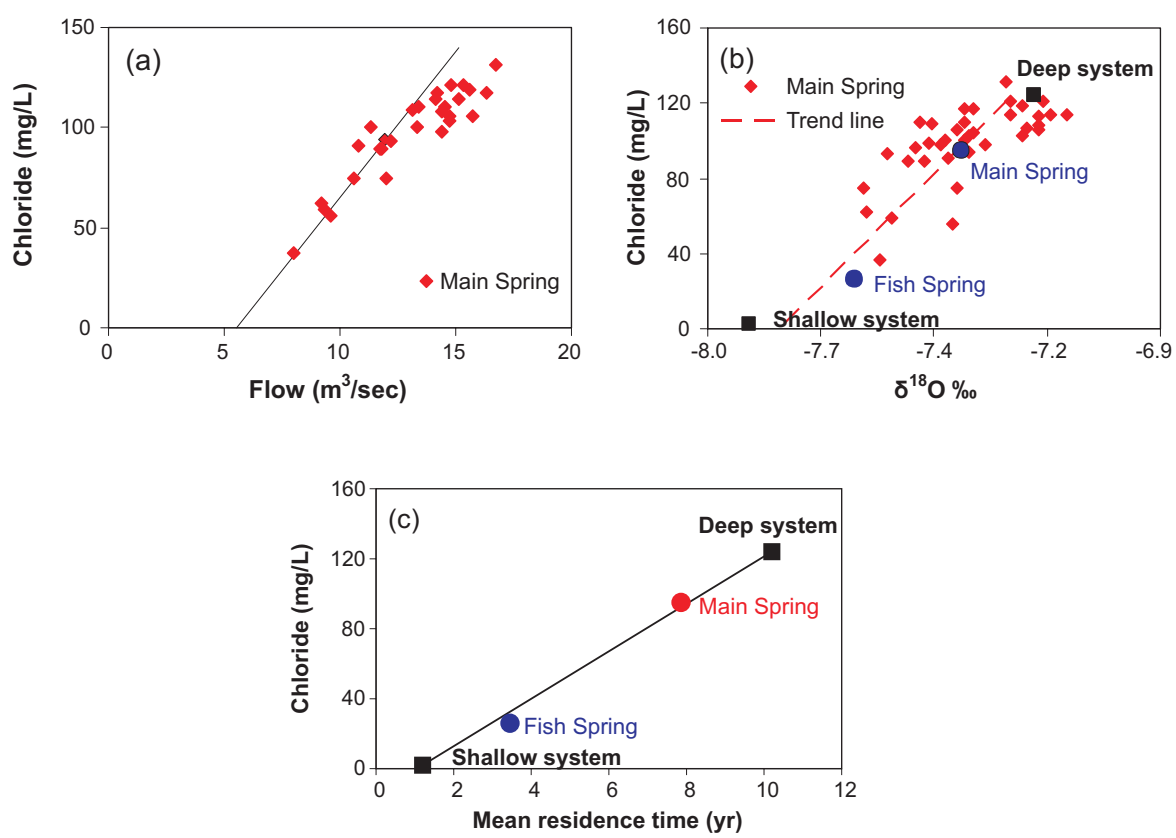

Fig. 5. (a) Plot of Springs River flow versus Main Spring chloride concentration. The line gives the approximate flow from the Pupu Springs. (b) Plot of $\delta^{18} \mathrm{O}$ values versus chloride concentration. The regression line is shown dashed. (c) Plot of MRT versus chloride concentration.

(required labelled "Remainder" in Table 4) to complete the ${ }^{18} \mathrm{O}$ balance. The $\delta^{18} \mathrm{O}$ value shows that most of the Remainder (75\%) must be from the Upper Takaka River (Table 4). Much of this flow is believed to be being discharged offshore via springs or seepages through the seabed, because no other large outflows from the system are known. Some small springs (of which Spring Brook is the largest, Edgar, 1998) occur between the mid-valley and the sea, but these are clearly insufficient to take the predicted flow.

Time lags in these recharge sources are considered to be short, although there is potential for streams collected on impervious catchments before reaching sinks in the marble to be delayed. However, the granite and schist have extremely low porosity and permeability and are classed as aquifuges not merely aquicludes (Ford and Williams, 1989). Both the karstic uplands streams and Upper Takaka River (except for a minor amount from the Waitui River catchment) collect water from granite and schist, which have no capacity to detain water in their catchments and hence will not produce time lags beyond a few months. In addition, tritium measurements for Upper Takaka River showed that the river water had at most a few months' residence time in its catchment (Taylor, 2000). Valley rainfall recharge has effectively zero time lag, because any such lag is part of the residence time estimated from the tritium measurements below.

\subsection{Chemical compositions}

The chemical compositions of some waters from the Takaka Valley are given in Table 5. The rivers, springs and bores were sampled in 1979 (Stewart and Downes, 1981). Two major trends dominate the water compositions. These are 1) interaction with carbonate rocks (marble and/or limestone), and 2) addition of sea water. More subtle interactions with the other lithologies tend to be masked by these trends.

Elevated concentrations of $\mathrm{Ca}, \mathrm{HCO}_{3}$ and $\mathrm{Sr}$ show the effects of interaction with carbonate rocks (samples from Ironstone Creek, Low's bore, CTWB, Main Spring and Fish Spring in Table 5). These waters are derived from Arthur Marble catchments or aquifers, except CTWB bore water which is from Takaka Limestone. Waters showing much less enrichment in $\mathrm{Ca}$, etc. are the Upper Takaka River and Dairy Co. bore, which derive water from non-carbonate rocks such as schist and granite. The Dairy Co. bore is in gravel probably recharged by the Takaka River.

Elevated $\mathrm{Na}, \mathrm{K}, \mathrm{Mg}, \mathrm{Cl}$ and $\mathrm{SO}_{4}$ concentrations in the Pupu Springs and Fish Creek Springs reveal seawater input (Michaelis, 1976; Stewart and Downes, 1981). Cl concentrations show that the Pupu Main Spring water contains 0.5\% sea water on average (amounting to 501/s in the average flow), Dancing Sands spring 0.4\% and Fish Creek Springs $0.1 \%$. However, the seawater content of Main Spring water varies between $0.2 \%$ at low flow $(8000 \mathrm{l} / \mathrm{s})$ and $0.65 \%$ at high flow (12000 1/s) (see Fig. 5a). Fig. 5a shows the total flow from the springs plus a small stream versus the $\mathrm{Cl}$ concentration in the Main Spring. The line gives the approximate flow from the springs if the stream water is removed. Seawater discharge is $161 / \mathrm{s}$ from the Main Spring during the lowest flow, and $801 / \mathrm{s}$ during the highest flow, a five-fold increase. Fish Creek Springs sea water discharge is 31 /s of seawater on average. 
The $\delta^{18} \mathrm{O}$ values of the Main Spring also vary with flow like the $\mathrm{Cl}$ concentrations. Figure $5 \mathrm{~b}$ shows the relationship between $\delta^{18} \mathrm{O}$ and $\mathrm{Cl}$. The approximately linear relationship indicates that the Main Spring can be considered to be fed by two main water components, whose proportions vary with discharge from the spring. The two end-member components of mixing are: deep system water with $\delta^{18} \mathrm{O}=-7.2 \%$ and $\mathrm{Cl}=124 \mathrm{mg} / \mathrm{l}$, and shallow system water with $\delta^{18} \mathrm{O}=-7.9 \%$ o and $\mathrm{Cl}=2 \mathrm{mg} / \mathrm{l}$ (Table 6 ). The $\delta^{18} \mathrm{O}$ value of the deep water is that of the karst uplands recharge, the shallow water $\delta^{18} \mathrm{O}$ is the weighted mean of the contributions from Upper Takaka River and valley rainfall to the Main Spring (Table 4). Note that the regression line (with $\delta^{18} \mathrm{O}$ as the $\mathrm{y}$-variable)

$\delta^{18} \mathrm{O}=(0.0046 \pm 0.0008) \mathrm{Cl}-(7.82 \pm 0.08)$

is little different from the line connecting the assumed endmembers

$\delta^{18} \mathrm{O}=0.0057 \mathrm{Cl}-7.90$.

The Main Spring points lie within experimental error of both lines (the standard deviations of the $\delta^{18} \mathrm{O}$ values around the lines are $\pm 0.096 \%$ and $\pm 0.101 \%$ o, respectively). The average values for the Main Spring and Fish Spring are also plotted on Fig. 5b.

Figure $5 c$ shows the (average) mean residence times of the Main Spring, Fish Spring and two water components versus chloride concentrations, from the residence time determinations described below. The relationships between flows, chloride, $\delta^{18} \mathrm{O}$ and ages (Fig. 5, Table 6) make it clear that the Main Spring water age decreases as its flow decreases, despite the age not being able to be determined on individual samples at different flows, i.e. as the flow from the Main Spring decreases, so the contribution of deep system water decreases, and therefore the age of the Main Spring water. This is contrary to the findings of most studies looking at the ages of springs (e.g. Siegenthaler et al., 1984). This is also counter-intuitive in that the shallow system water provides more of the flow during low-flow (base-flow) conditions.

\subsection{Residence time estimation: Tritium and CFCs}

Reliable interpretation of the tritium ages of the springs requires that the input of tritium to the groundwater aquifer be known. This involves knowing both the tritium concentration in the precipitation and how it is affected during recharge to the AMA. Tritium concentration in precipitation is taken from monthly measurements at Kaitoke near Wellington, adjusted by a scale factor. The scale factor adjusts precipitation data for well-known latitudinal and altitudinal variations over New Zealand (Stewart and Taylor, 1981).

The latitudes of both Kaitoke and Takaka Valley are close to $41^{\circ} 00^{\prime} \mathrm{S}$, and both are within mountainous terrain affected by the dominant westerlies (see inset in Fig. 1). Kaitoke is at $180 \mathrm{~m}$ altitude (all altitudes are given relative to mean sea level), but the precipitation-weighted mean altitude of the
Table 6. Average compositions of Pupu Springs and component waters.

\begin{tabular}{lrrrr}
\hline Sample & $b$ & $\mathrm{Cl}(\mathrm{mg} / \mathrm{l})$ & $\delta^{18} \mathrm{O}(\% \circ)$ & $\mathrm{MRT}(\mathrm{yr})$ \\
\hline Deep system water & 0 & 124 & -7.20 & 10.2 \\
Main Spring & 0.26 & 95 & -7.38 & 7.9 \\
Fish Spring & 0.75 & 26 & -7.64 & 3.5 \\
Shallow system water & 1 & 2 & -7.90 & 1.2 \\
\hline
\end{tabular}

catchment of the Hutt River at Kaitoke was estimated to be $610 \mathrm{~m}$ (Stewart et al., 1983) and this is taken as the appropriate altitude affecting the precipitation. The Pupu Springs are at $14 \mathrm{~m}$ altitude, and the precipitation-weighted mean altitudes of the Upper Takaka River, karst uplands and valley rainfall catchment areas are estimated to be $1100 \mathrm{~m}, 460 \mathrm{~m}$ and $100 \mathrm{~m}$, respectively. Applying the recharge model in Table 4 gives mean altitudes of recharge of $546 \mathrm{~m}$ for Main Spring and $690 \mathrm{~m}$ for Fish Spring, both similar to that at Kaitoke and indicating that the scale factor should be taken as 1.0 .

The effect of the recharge process (i.e. seasonal selection of precipitation) on the isotopic composition of infiltrated water has been considered for ${ }^{18} \mathrm{O}$ (both in estimating the average values above, and for the individual monthly values below). The effect is much greater for the monthly ${ }^{18} \mathrm{O}$ values than for the annual tritium values. This is because using annual means instead of monthly tritium data smooths the seasonal selection effect of the spring tritium peak (Stewart and Taylor, 1981). Also as noted for ${ }^{18} \mathrm{O}$, the dominant recharge is from the karst uplands and Upper Takaka River, and is mainly via concentrated inputs (sinks). Consequently, the effect of seasonal selection via evapotranspiration will be small. Finally, any effect tends to be counteracted by peak flows reaching the ends of the streams more frequently in winter, which acts to produce a more constant amount of recharge through the year. Recharge from valley rainfall, which is subject to evapotranspiration, is a relatively small contributor to the AMA. For these reasons, the effect of the recharge process is taken as negligible.

Chlorofluorocarbons or CFCs are entirely man-made contaminants of the atmosphere and hydrological systems. Their concentrations in the atmosphere gradually increased from zero in 1940 to peaks in the early 1990s (Plummer and Busenberg, 2001). Because the gases are relatively longlived (with CFC-11 half-life being $45 \pm 7 \mathrm{yr}$ and CFC-12 $87 \pm 17 \mathrm{yr}$ ), they are widely distributed in the atmosphere. CFCs are slightly soluble in water and enter groundwater systems along with water during recharge. Assuming that they were in solubility equilibrium, their concentrations in groundwater record the atmospheric concentrations when the water was recharged, thus allowing the recharge date of the water to be determined. The temperature and atmospheric pressure (i.e. altitude) during recharge need to be known. 
Table 7. Tritium and CFC concentrations in Takaka waters, and $\mathrm{Cl}$ concentration for Main Spring.

\begin{tabular}{lrrrr}
\hline Date & Main Spring Cl & Main Spring & Fish Spring & Balls bore \\
\hline $\mathrm{mg} / \mathrm{l}$ & \multicolumn{3}{c}{ Tritium in TU } & \\
\hline 27 May 1966 & 116 & $14.0 \pm 0.9$ & & \\
29 July 1972 & 93 & $15.2 \pm 1.9$ & & \\
20 March 1976 & 98 & $11.0 \pm 1.2$ & & \\
26 Feb 1998 & 78 & $2.25 \pm 0.06$ & & \\
16 March 1999 & & $2.08 \pm 0.08$ & & \\
25 Aug 2000 & & & $1.96 \pm 0.06$ & \\
15 June 2005 & & $1.42 \pm 0.04$ & & \\
21 March 2006 & & $1.53 \pm 0.05$ & &
\end{tabular}

\begin{tabular}{|c|c|c|c|c|}
\hline & & \multicolumn{3}{|c|}{ CFC-11 in pptv } \\
\hline 26 Feb 1998 & 78 & $206.1 \pm 4.7$ & & $109.3 \pm 4.7$ \\
\hline 21 Feb 2000 & & $207.8 \pm 1.1$ & & \\
\hline 25 Aug 2000 & & & $243.9 \pm 2.8$ & \\
\hline \multirow[t]{2}{*}{3 Sep 2002} & & & $250.8 \pm 6.6$ & $112.0 \pm 0.2$ \\
\hline & & \multicolumn{3}{|c|}{ CFC-12 in pptv } \\
\hline 26 Feb 1998 & 78 & $453.6 \pm 6.5$ & & $264.5 \pm 1.0$ \\
\hline 21 Feb 2000 & & $446.3 \pm 1.5$ & & \\
\hline 25 Aug 2000 & & & $502.6 \pm 7.1$ & \\
\hline 3 Sep 2002 & & $468.1 \pm 2.5$ & $487.9 \pm 1.9$ & $225.3 \pm 0.4$ \\
\hline
\end{tabular}

The concentrations of the gases in groundwater can also be affected by several other processes, which can make age interpretation complicated (Plummer and Busenberg, 2001). The most important of these in the present context are:

1. Possible degradation or absorption in anaerobic conditions underground (CFC-11 is more susceptible to this than CFC-12). This has not been observed in the present data.

2. Possible contamination from local sources such as organic liquids (CFC-12 is more prone to this than CFC11). This has also not been observed in the present data.

3. Presence of excess air in solution (CFC-12 is mildly sensitive to this, and CFC-11 much less). We have assumed that there is no excess air in the present samples. If excess air was present, this assumption would have caused our estimated ages to be too young.

4. Unsaturated zone effect: CFCs could travel more rapidly through the unsaturated zone than tritium, because gases can travel in the soil gas phase while tritium travels with water. This means that gas ages could be expected to be younger than tritium ages in systems with substantial unsaturated zones. However, much of the recharge in this catchment occurs via sinks and sinkholes, so this is unlikely to be a problem for these samples.
CFC measurements have given useful information on water residence times in a number of New Zealand groundwater systems (Stewart and Morgenstern 2001). We have found that groundwater ages estimated using CFC-11 and tritium are often in agreement, whereas ages estimated using CFC12 are generally several years younger.

\subsubsection{Main spring}

Measurements of tritium concentrations in the Pupu Springs and other waters are given in Table 7. Tritium measurements for the Main Spring span $40 \mathrm{yr}$, almost covering the rise and fall of tritium concentration in the atmosphere due to testing of nuclear weapons in the 1950s and 1960s. Consequently, the problem of determining the mean residence time (MRT) from tritium is well-constrained. The Main Spring accumulates water from a large area and from a wide variety of sources, so it is expected that the water will have a wide distribution of transit times. Three such flow models have been applied to interpret the tritium age.

The flow models are the exponential piston flow (EPM), dispersion (DM) and double dispersion (DDM) models. The DDM model is based on the 2-component flow system inferred from the $\delta^{18} \mathrm{O}$ and $\mathrm{Cl}$ measurements above.

Figure 6a shows the tritium concentrations in the recharge, the data for the Main Spring, and the best-fitting model simulations. The residence time distributions of the models (Fig. 6b) have very similar shapes with peaks of very young 
water and long tails of much older water. The variation of the quality of the fits with MRT is shown in Fig. 6c, with the goodness-of-fit being expressed as the standard of deviation (sd) of the measurements about the simulations. For the DDM model, the overall MRT was varied by changing the MRT of the deep component.

All three models give good fits to the data, and the mean residence times are sharply constrained close to $8 \mathrm{yr}$, despite the larger errors in the early tritium measurements (because there were also large variations in the tritium input from year to year at that time). The best EPM model has mean residence time (MRT) of $7.9 \mathrm{yr}$, exponential fraction $(f)$ of 0.95 (i.e. it is close to an exponential model), and goodness-of-fit $(s d)$ of $\pm 0.40 \mathrm{TU}$. The best DM model has MRT $8.2 \mathrm{yr}$, dispersion parameter (DP) of 1.8 , and sd of \pm 0.29 TU. Its age distribution is almost the same as that of the DDM model, except for the smaller peak of very young water. The best fitting DDM model fits very well indeed ( $s d$ is $\pm 0.08 \mathrm{TU}$ ). It has an overall MRT of $7.9 \mathrm{yr}$, with $74 \%$ of the water being 10.2 years old and $26 \%$ being $1.2 \mathrm{yr}$ old. The parameters of the models are given in Table 8.

Note that the MRT determined is an average, because it is expected to vary with flow (Fig. 5). The chloride values for the Main Spring (Table 7) give an indication of the flow when the spring was sampled. Mean $\mathrm{Cl}$ for the Main Spring was $95 \mathrm{mg} / \mathrm{l}$ (Table 6), so the 1966 sample was sampled during above average flow, the 1972 and 1976 samples during average flows and the 1999 sample during less than average flow.

CFC measurements are given in Table 7. CFC samples were collected in 1998 and 2000. For CFC-11, applying the $\operatorname{EPM}(f=0.95)$ model gives the best-fit MRT of $12.2 \mathrm{yr}$, and the $\mathrm{DM}(\mathrm{DP}=1.8)$ model MRT of $4.8 \mathrm{yr}$, both quite different from each other and from the tritium result. Applying the DDM model with the same water components as for tritium, but optimising the fit by varying the young fraction $(b)$, gives a best-fit model with $b=0.24$ and overall MRT of $8.0 \mathrm{yr}$, very similar to that for tritium. This suggests that the DDM age distribution has more validity in this system than the other two models (EPM and DM), and supports the conceptual model below. Model parameters are given in Table 8 .

For CFC-12, the best-fit MRTs with the same models (i.e. keeping the other parameters the same) are $9.2 \mathrm{yr}, 3.2 \mathrm{yr}$ and $5.7 \mathrm{yr}(b=0.50)$, respectively. None of these agree well with the results for tritium and CFC-11. This is consistent with our previous observations that $\mathrm{CFC}-12$ frequently gives younger residence times than tritium and CFC-11 (Stewart and Morgenstern 2001).

To compare the sensitivities of the tritium result with the $\mathrm{CFC}$ results we have plotted the goodness-of-fit $(s d)$ divided by the measurement error $(\varepsilon)$ against $b$ in Fig. 7a. (For tritium, the error has been taken as the root mean square of the first three measurements when the quoted errors were much larger than for the later samples.) The best-fit values of $b$ for tritium and CFC-11 are close to the value calculated from the
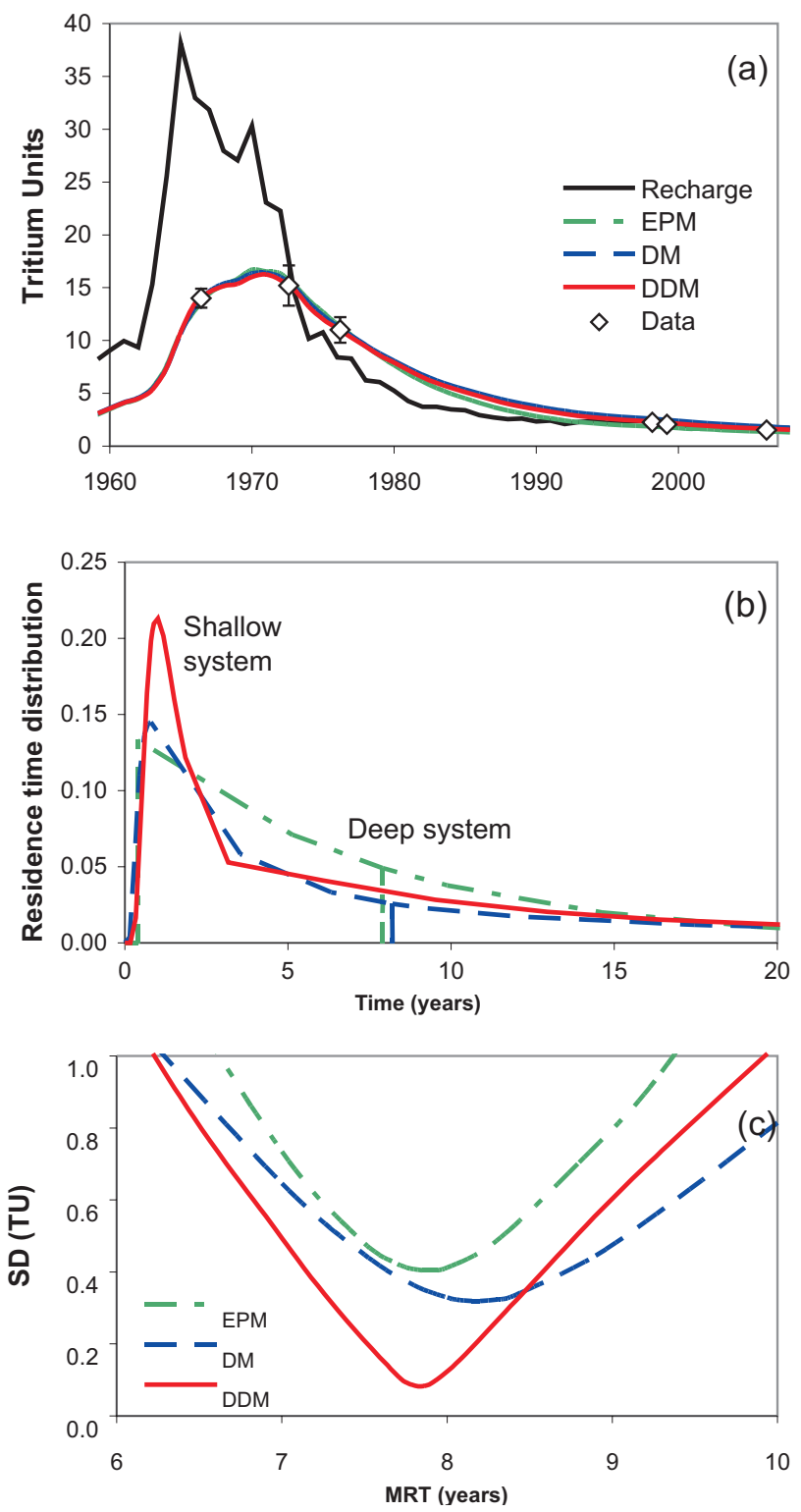

Fig. 6. Tritium results for the Main Spring. (a) Tritium concentrations in recharge, best-fit simulation models and spring water. (b) Mean residence time distributions for the best-fit simulation models. (c) Variation of the goodness-of-fit criterion with MRT.

recharge flows in Table 4 (shown by the dashed vertical line in Fig. 7a). As noted, the CFC-12 value is quite different and has been disregarded.

\subsubsection{Fish spring}

Fish Spring results are given in Table 7. The EPM and DM models with broad distributions are not effective for estimating the ages of the Fish Spring (the ages are not consistent with each other), but the DDM model appears to work well (Table 8). Applying the DDM model to tritium and allowing 

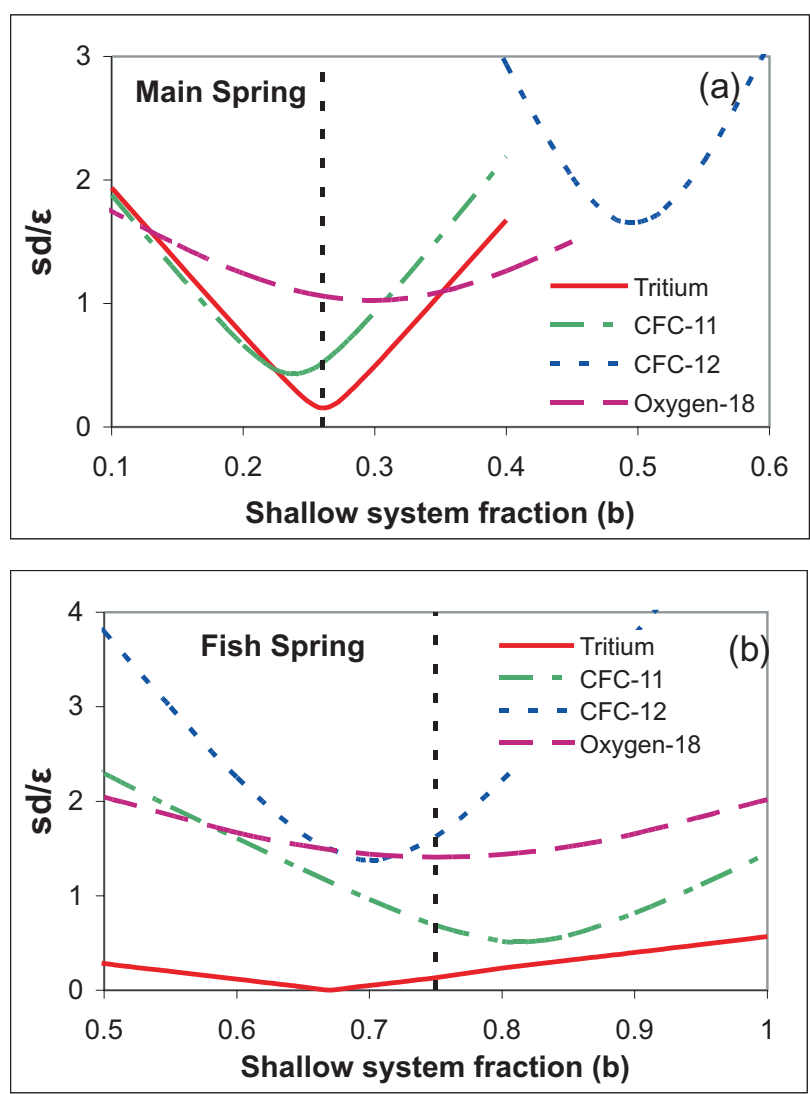

Fig. 7. Variation of the goodness-of-fit criterion with shallow system fraction $b$ for tritium, CFC-11, CFC-12 and oxygen-18 results, for (a) Main Spring, (b) Fish Spring.

the young fraction to vary gives a best-fit model with $b=0.67$ (Fig. 7b). Applying the model to the two CFC-11 measurements gives a best fit at $b=0.81$. With CFC-12, the best-fit model is $b=0.70$. These are all relatively close to the value calculated from the recharge flows in Table 4 (i.e. $b=0.75$, shown by the dashed vertical line in Fig. 7b). In this case, the CFC-12 measurements appear to have given an acceptable result (unlike for the Main Spring). This is possibly due to the dominance of the younger component in Fish Spring water.

\subsubsection{Balls bore}

Balls bore (WWD 6011) is a deep well (114 m) with a long unscreened interval located approximately $425 \mathrm{~m}$ southwest of the Main Spring (Fig. 3). The bore penetrates $33 \mathrm{~m}$ of Motupipi Coal Measures before encountering fractured Arthur Marble, and is cased to $35 \mathrm{~m}$ depth. The ground level is $21 \mathrm{~m}$ a.s.l. compared with $14 \mathrm{~m}$ at the Main Spring and $17 \mathrm{~m}$ at Fish Spring. Rest water level (with no pumping) in the bore is $18 \mathrm{~m}$ a.s.l.

The $\delta^{18} \mathrm{O}$ value of the water is $-6.48 \%$, indicating a dominance of valley rainfall and likely absence of Upper Takaka River water. Tritium and CFC results are given in Table 7. To obtain a consistent age from the tritium and CFC measurements, R. van der Raaij (pers. comm., 2006) found he had to assume binary mixing of two source waters. The mixture comprised approximately two thirds of 1-yr-old water (assumed to be from shallow level) and one third of much older water (containing zero tritium and CFCs and therefore probably at least 100 -yr-old) from depth. The $\delta^{18} \mathrm{O}$ value is consistent with two thirds 1-yr-old water being sourced from valley rainfall, and one third 100-yr-old water from karst uplands.

The result is interesting, because it emphasises how laterally inhomogeneous and stratified the AMA is. Clearly waters with very different residence times and sources can be drawn from different parts of the aquifer. The 1-yr-old shallow water component is like that observed at the Pupu Springs, but with a different source. The 100 -yr-old water is likely to be from the fissured-porous matrix reflecting the fact that there is no natural outflow and few or much smaller deep fissures at this site. (e.g. Drawdown with pumping is considerable, being $3.2 \mathrm{~m}$ with $10.7 \mathrm{l} / \mathrm{s}$ water extraction.)

4.5 Residence time estimation of the shallow component: Oxygen-18 variations

The $\delta^{18} \mathrm{O}$ variations in the Main and Fish Springs can be used to estimate the mean residence time of the shallow component (MRT about $1.2 \mathrm{yr}$ ). The deep component (MRT=10.2 yr) has too long a residence time to show any variations due to the $\delta^{18} \mathrm{O}$ variations in its input water, so its $\delta^{18} \mathrm{O}$ value can be assumed to be constant at $\delta^{18} \mathrm{O}=-7.2 \%$. But the shallow component water should be young enough to show effects from the $\delta^{18} \mathrm{O}$ variations of its inputs.

The input $\delta^{18} \mathrm{O}$ values of the shallow system can be calculated by correcting the valley rainfall data (site 8 ) for evapotranspiration and the Upper Takaka River data (site 1) for river loss to the underlying aquifer by the method described in Stewart et al. (2007). (To determine river loss to the underlying aquifer, river flows up to the maximum that could be accepted by the aquifer were used.) The calculations use the weighting formula given by Bergmann et al. (1986)

$\delta_{w}=\frac{R_{i}}{R_{\text {mean }}}\left(\delta_{i}-\delta_{\text {mean }}\right)+\delta_{\text {mean }}$

where $\delta_{w}, \delta_{i}$ are the weighted and measured $\delta^{18} \mathrm{O}$ values, and $R_{i}$ the groundwater recharge amount, in the $i$ th month, respectively. $\delta_{\text {mean }}$ and $R_{\text {mean }}$ are the mean $\delta^{18} \mathrm{O}$ values and recharge amounts.

The $\delta^{18} \mathrm{O}$ values of the recharge for Main Spring are given by

$\delta_{\mathrm{MSrech}}=b\left(0.29 \delta_{\mathrm{wrf}}+0.71 \delta_{\mathrm{wUTR}}\right)+(1-b) \delta_{\mathrm{wku}}$

and that for Fish Spring is

$\delta_{\mathrm{FSrech}}=b\left(0.33 \delta_{\mathrm{wrf}}+0.67 \delta_{\mathrm{wUTR}}\right)+(1-b) \delta_{\mathrm{wku}}$ 

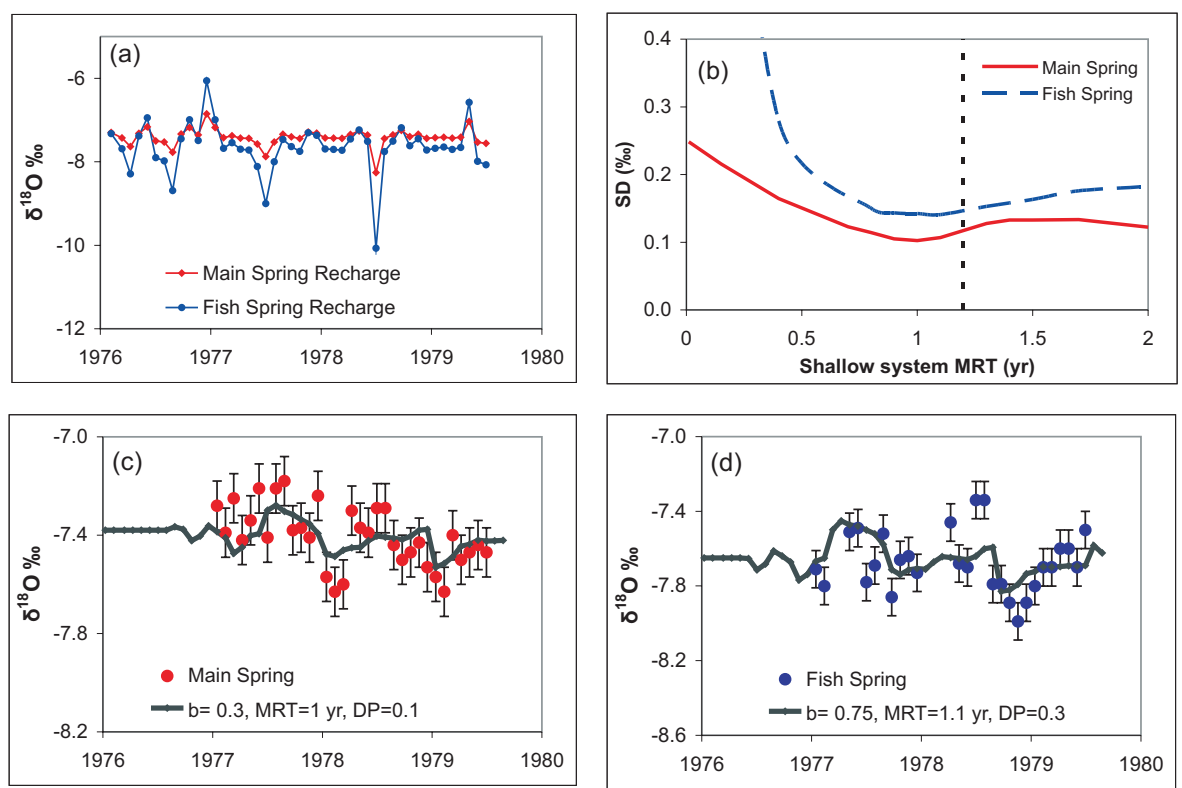

Fig. 8. Oxygen-18 results for the Main and Fish Springs. (a) $\delta^{18} \mathrm{O}$ variations in recharge to the springs. (b) Variation of the goodness-of-fit criterion with shallow system MRT. (c) Measurements and simulation for the Main Spring. (d) Measurements and simulation for Fish Spring.

where $b$ is the shallow fraction, and $\delta_{\mathrm{wrf}}, \delta_{\mathrm{wUTR}}, \delta_{\mathrm{wku}}$ are the weighted $\delta^{18} \mathrm{O}$ values for valley rainfall, Upper Takaka River and karst uplands (-7.2\%o), respectively, from Eq. (9). The multiplying factors are the ratios of the flows in Table 4. Fig. 8a shows the calculated $\delta^{18} \mathrm{O}$ variations in the recharge for the two springs.

Three adjustable parameters were used to simulate the $\delta^{18} \mathrm{O}$ values of the Main Spring, namely $b$, and the MRT and DP of the shallow water. The variation of the goodness-offit parameter with MRT is shown in Fig. 8b, and the bestfitting simulation is given in Fig. 8c. (The first 12 measurements were omitted because they would have been affected by recharge before the measurements on valley rainfall and Upper Takaka River had begun.) The best fit is obtained with MRT $=1.0 \mathrm{yr}, \mathrm{DP}=0.1$ and $b=0.3$, which are all close to the values obtained from the earlier work (i.e. $\mathrm{MRT}=1.2 \mathrm{yr}, \mathrm{DP}=0.12, b=0.26$ ). This gives good support to the 2-component model.

The same three parameters were used to fit the $\delta^{18} \mathrm{O}$ values of the Fish Spring. The optimum fit is obtained with $\mathrm{MRT}=1.1 \mathrm{yr}, \mathrm{DP}=0.3, b=0.75$ (Figs. $8 \mathrm{~b}, \mathrm{~d}$ ). These also agree well with the parameters from the earlier work $(\mathrm{MRT}=1.2 \mathrm{yr}$, $\mathrm{DP}=0.12, b=0.75)$.

The variation of the quality of fit with $b$ is compared with those for tritium and CFCs in Fig. 7a, b. The optimum fits occur at close to the same values of $b$ as with the other tracers (Table 8), and therefore strongly support the 2-component model for the springs, and in particular the existence of the shallow component with MRT about $1.2 \mathrm{yr}$.
One source of error in the estimation of the $\delta^{18} \mathrm{O}$ values of the recharge to the springs is the assumption that $b$ and the proportions of Upper Takaka River and valley rainfall waters are constant. In fact, these are likely to vary in time as the catchment wetness and therefore spring flow varies.

\section{Discussion}

\subsection{Karst hydrology}

Karst landscapes are produced by groundwaters percolating through limestone rock and gradually dissolving the carbonate minerals. Limestones are commonly well-jointed, and water initially penetrates slowly along joints. In time, solution of carbonate minerals by the water gradually widens the joints into fissures. Eventually an interconnected system of solution cavities forms allowing water to move easily from sinks in the recharge area through the rock to emerge as springs at the foot of the catchment.

Arthur Marble is a thermally metamorphosed limestone produced by recrystallisation of the constituent carbonate grains. The development of a crystalline matrix will have reduced the primary matrix porosity of the original limestone, and solution of the joints will have enhanced the secondary conduit permeability. Consequently, the rates of flow in the two media of pores and solution cavities will differ by orders of magnitude producing a markedly dual porosity aquifer.

The idea of karst hydrology being controlled by two integrated subsystems with different porosities (representing 
Table 8. Results of model simulations for the Main and Fish Springs. EPM is the exponential-piston flow model, DM the dispersion model and DDM the double dispersion or 2-component model. The overall MRT for the DDM model is given by $\tau_{o}=b \tau_{s}+(1-b) \tau_{d}$.

\begin{tabular}{|c|c|c|c|c|c|c|c|c|}
\hline \multicolumn{2}{|c|}{ Model (parameters) } & \multicolumn{2}{|c|}{$\mathrm{EPM}(f=0.95)$} & \multicolumn{2}{|c|}{$\mathrm{DM}(\mathrm{DP}=1.8)$} & \multicolumn{3}{|c|}{$\begin{array}{c}\operatorname{DDM}\left(\tau_{s}=1.2 \mathrm{yr}, \mathrm{DP}_{s}=0.12,\right) \\
\quad\left(\tau_{d}=10.2 \mathrm{yr}, \mathrm{DP}_{d}=0.6\right)\end{array}$} \\
\hline & & $\tau_{m} \mathrm{yr}$ & $s d^{1}$ & $\tau_{m} \mathrm{yr}$ & $s d$ & $b$ & $\tau_{o} \mathrm{yr}$ & $s d$ \\
\hline \multirow[t]{5}{*}{ Main Spring } & Table 4 & - & - & - & - & 0.26 & - & - \\
\hline & Tritium & 7.9 & $\pm 0.40 \mathrm{TU}$ & 8.2 & $\pm 0.29 \mathrm{TU}$ & 0.26 & 7.9 & $\pm 0.08 \mathrm{TU}$ \\
\hline & CFC-11 & 12.2 & $\pm 2.4 \mathrm{pptv}$ & 4.8 & \pm 0.9 pptv & 0.24 & 8.0 & $\pm 1.5 \mathrm{pptv}$ \\
\hline & CFC-12 & 9.2 & $\pm 8.5 \mathrm{pptv}$ & 3.2 & $\pm 7.0 \mathrm{pptv}$ & 0.50 & 5.7 & $\pm 6.8 \mathrm{pptv}$ \\
\hline & Oxygen-18 & - & - & - & - & 0.30 & - & $\pm 0.10 \%$ \\
\hline \multirow[t]{5}{*}{ Fish Spring } & Table 4 & - & - & - & - & 0.75 & - & - \\
\hline & Tritium & $0.0^{1}$ & $\pm 0.03 \mathrm{TU}$ & 0.9 & $\pm 0.00 \mathrm{TU}$ & 0.67 & 4.2 & $\pm 0.00 \mathrm{TU}$ \\
\hline & CFC-11 & 7.1 & $\pm 1.4 \mathrm{pptv}$ & 1.7 & $\pm 2.1 \mathrm{pptv}$ & 0.81 & 2.9 & $\pm 2.6 \mathrm{pptv}$ \\
\hline & CFC-12 & 7.1 & $\pm 8.9 \mathrm{pptv}$ & 2.1 & $\pm 7.8 \mathrm{pptv}$ & 0.70 & 3.9 & $\pm 7.2 \mathrm{pptv}$ \\
\hline & Oxygen-18 & - & - & - & - & 0.75 & - & $\pm 0.14 \%$ \\
\hline
\end{tabular}

${ }^{1} s d$ is the goodness-of-fit criterion expressed as the standard deviation of the measurements about the simulated curve.

fissured-porous matrix and solution cavities, respectively) has been used very widely in karst studies (e.g. page 1, Ford and Williams, 1989), and has been applied to interpret tritium and oxygen-18 measurements in karst springs by Rank et al. (1992), Maloszewski et al. (2002). Fig. 9a (adapted from Maloszewski et al., 2002) illustrates the nature of flow in karst aquifers. Connected porosity occurs in small-scale fissures and porous matrix of the marble providing the majority of the storage in the system (the fissured-porous aquifer), and a low-volume but high-velocity conduit system (karstic channels) conveys water from entrances to exits while interacting with water in small fissures and pores on the way.

\subsection{Conceptual model of the AMA flow system}

The conceptual model presented here (Fig. 9b), however, is different. It is based on the measurements and deductions described above. The AMA flow system supplying the Pupu Springs is conceived of as containing two flow systems, each being dual porosity aquifers like that illustrated schematically in Fig. 9a. Springs generally draw on deeper groundwater sources during low flow conditions, with the water becoming older as flow decreases. And, in particular, springs fed by the dual porosity aquifer of Fig. 9a would become older with decreasing flow because more of the water would come from the fissured-porous matrix. However, the opposite happens with the Pupu Springs, the water becomes younger as flow decreases (Fig. 5). This leads logically to the idea of two flow systems with different recharge sources.

The deep system supplies the majority of the flow to the Main Spring complex via one or more major fissures or solution channels, which connect the deep fissure network to the springs. The system includes the deep parts of the marble below the Takaka Valley floor and the marble on both sides of the valley. The marble outcrops on the sides of the valley show strong evidence of karstification, based on surface expression and the presence of caves (with the most famous cave being Harwood's Hole with a $183 \mathrm{~m}$ vertical drop). The marble beneath the valley will also have been karstified down to at least $130 \mathrm{~m}$ during lower sea-level stands. ${ }^{18} \mathrm{O}$ evidence shows that recharge for the deep water component is from the small tributary streams and rainfall on the karst uplands on each side of the valley. The pressure from the higher water tables on the sides of the valley (especially the karst plateau on the east side), transmitted by the solution channel network, plus the confining layer in the lower valley, produce high piezometric levels in the confined area. Most of the deep system recharge eventually emerges at the Main Spring complex where the confining layer thins - about $80 \%$ of the water entering the deep system is discharged by the Main Spring complex on average (Table 4). Lesser amounts emerge in the Fish Creek Springs (9\%) and the rest can probably be accounted for by seepages upwards into the mostly overlying shallow system. Hence, it is unlikely that much water escapes into the sea from the deep system, in spite of the evident presence of sea water at depth in the aquifer. The source of the sea water is believed to be present-day infiltration (possibly by a venturi effect, Williams, 1977; Fleury et al., 2007). The powerful upflow in the deep system near the springs carries sea water from depth into the springs' discharge.

The part of the DDM model representing the deep system water (i.e. the $\mathrm{DM}$ with $\mathrm{DP}_{d}=0.6, \tau_{d}=10.2 \mathrm{yr}$ ) has a broad flat profile indicating a very wide distribution of residence times, peaked at $3 \mathrm{yr}$ but with a very long tail of older ages (Fig. 6b). The younger water probably flows in larger channels, while the much larger volume of older water experiences greater retardation in the fissured-porous matrix. The mean residence time of the deep system water is long (10.2 yr) and the storage capacity of the aquifer very large (water volume 
estimated from flow times age $=9200 \mathrm{l} / \mathrm{s} \times 10.2 \mathrm{yr}=3.0 \mathrm{~km}^{3}$ ). Much of the saturated part of the system is below sea level. Interaction between channel network water and fissuredporous matrix water may affect the chemical and isotopic concentrations of the channel water (e.g. Elliot et al., 1999), although the marble is expected to have very low primary porosity. There is possibly much older water resident in less accessible parts of the fissured-porous matrix, as shown by the results for Balls bore.

The shallow system underlies the Takaka Valley. The unconfined part in the Central Valley includes Arthur Marble, Takaka Limestone and Takaka Gravel, while the confined part in the Lower Valley is in Arthur Marble beneath the Motupipi Coal Measures. Recharge is from both the Upper Takaka River and valley rainfall. Much of the water (52\%) bypasses the Pupu Springs and is discharged offshore in springs and seeps, some (25\%) appears in the Main Spring complex and $23 \%$ in the Fish Creek Springs (Table 4).

The shallow system residence time distribution $\left(\mathrm{DP}_{s}=0.12, \tau_{s}=1.2 \mathrm{yr}\right.$, Fig. $\left.6 \mathrm{~b}\right)$ has a much narrower distribution of residence times than that for the deep system. It is peaked at $0.9 \mathrm{yr}$ and moderately skewed to older ages. It appears from the distribution that water is not able to flow directly to the springs in large karstic channels, because in that case very much younger water would be seen (water with ages of one month or less). However, it is probable that any such channels would be gravel-choked, and this may be one reason for the absence of very young water. The relatively narrow distribution suggests flow beneath the confining Motupipi Coal Measures approximates piston-flow, with combination of much more heterogeneous flowpaths in the unconfined area in the Central Takaka Valley. The water discharged in the Pupu Springs is estimated to have a mean residence time of $1.2 \mathrm{yr}$, leading to a water volume (estimated from flow times age) of $0.4 \mathrm{~km}^{3}$.

5.3 Location of the pupu springs and the relationship between the two flow systems

A question that arises is: why do these two systems act as if they are separate, although apparently residing in the same aquifer? Williams (1977) discussed the related question of why the springs are located in a small tributary valley on the west side of the Takaka fault-angle valley, and $5 \mathrm{~km}$ from the line of shortest distance between the upper valley and the sea. $\mathrm{He}$ found this a surprising location, and considered that there must be a special local circumstance at Takaka to explain it. One of his hypothesised explanations for the location helps to shed light on the relationship between the two systems.

Williams had two alternative explanations for the location of the springs. The first was that the marble is more limited in extent than shown in Fig. 1 and strikes in the direction of Pupu, thereby channelling the flow in that direction. This is not considered a viable explanation in view of the geology and the current results. The second explanation was
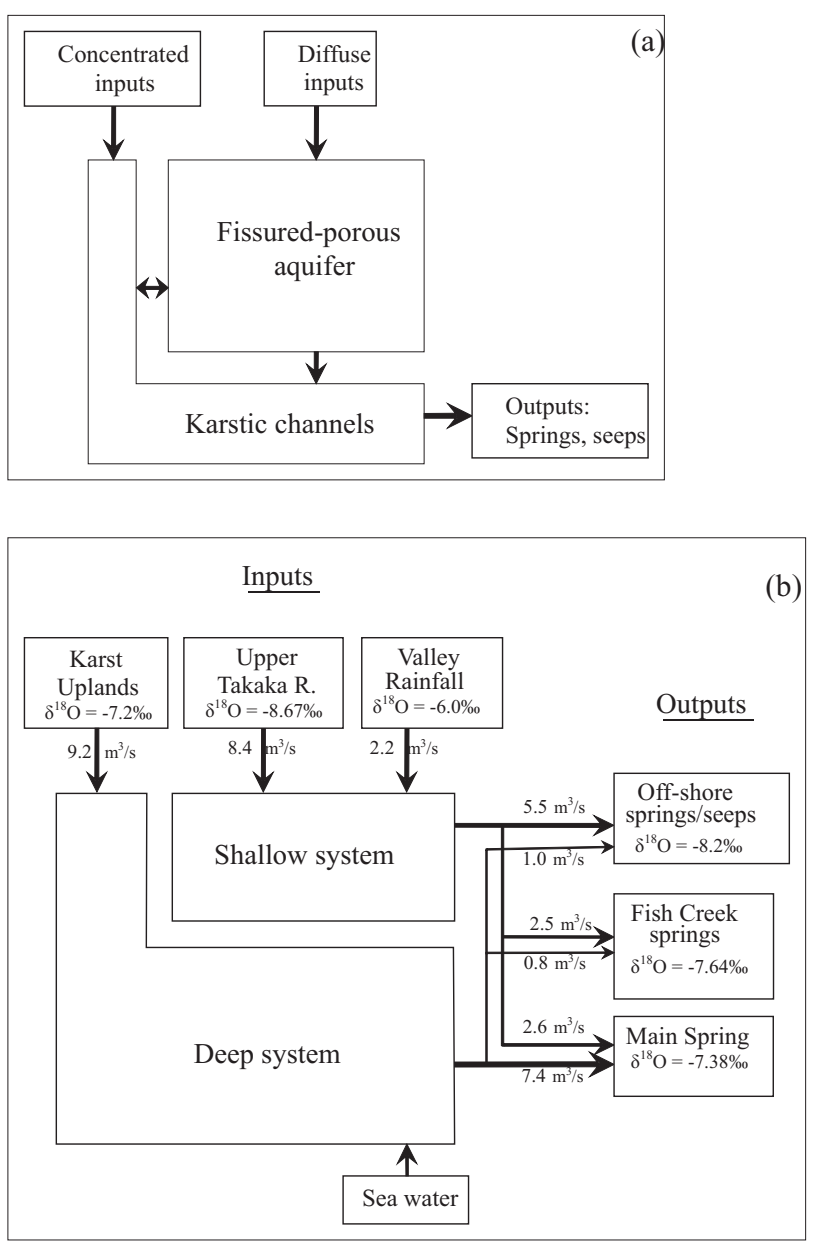

Fig. 9. Conceptual model of flow in the Arthur Marble Aquifer. (a) Schematic of flow in karst systems. (b) The relationship of inputs, flow systems and outputs in the AMA. The internal structure of the flow systems are as illustrated in (a). Average flows and $\delta^{18} \mathrm{O}$ values are shown.

that there is a diorite intrusion in the marble at shallow levels under the Takaka Valley, which blocks water in the deep system from flowing towards the sea. The diorite, which is not shown on geological maps of the area (Rattenbury et al., 1998), was suggested by Jones (1939) from a survey of magnetic anomalies in the Takaka region. Jones's zero magnetic anomaly outline for the suggested intrusive is shown in Fig. 1. The diorite, which lies parallel to and is shown on Section A in Fig. 2, would divert water in the deep system very effectively towards the Pupu Springs in the west, while allowing the shallow system water to flow over the intrusion and escape via submarine outlets. The Pupu Springs themselves, occurring where the cap rock is thinnest and artesian pressures highest, would also induce convergence of flow and draw both deep water, and a proportion of the shallow water to the springs. 


\section{Conclusions}

The paper examines the evidence on recharge sources to the AMA and establishes a new recharge model using the most reliable information. This recharge model is used with estimates of the average $\delta^{18} \mathrm{O}$ values of the three groups of recharge sources to derive an ${ }^{18} \mathrm{O}$ mass balance for the inputs and outputs of the AMA by means of a spreadsheet (Table 4). The results show that the Main Spring is sourced mainly from the karst uplands (74\%), with smaller contributions from the Upper Takaka River (18\%) and valley rainfall (8\%). In contrast, Fish Creek Springs are fed mainly by Upper Takaka River $(50 \%)$, with valley rainfall $(25 \%)$ and karst uplands $(25 \%)$. The unexpected consequence of the mass balance is that much of the Upper Takaka River contribution to the aquifer $(58 \%)$ must bypass the springs and be discharged via offshore springs and seeps.

The chemical concentrations of the Pupu Springs reflect input of sea water, at average rates of $0.5 \%$ in the Main Spring and $0.1 \%$ in Fish Creek Springs, carried by deep system water. Monthly variations in the chloride and oxygen-18 concentrations of the Main Spring point to a two-component flow system. Tritium measurements spanning $40 \mathrm{yr}$, and CFC-11 measurements, give a mean residence time of $8 \mathrm{yr}$ for the Main Spring water. Fish Spring water has mean transit time of $3.5 \mathrm{yr}$. The measurements are best explained by a two-component model, with different proportions of deep (MRT $10.2 \mathrm{yr}$ ) and shallow (MRT $1.2 \mathrm{yr}$ ) components contributing to each spring. The monthly ${ }^{18} \mathrm{O}$ measurements on the springs corroborate the proportions and transit time of the shallow component in the spring flows.

These observations are integrated in a conceptual model of flow in the AMA (Fig. 9b). The three groups of recharge sources supply two flow systems. The first is a deep aquifer, which underlies the Takaka Valley and crops out (and is recharged) on each side in the karst uplands (Fig. 2). Higher water tables on the sides drive the deep flow, which surges upwards at the Main Spring complex, discharging most (average $80 \%$ ) of the karst uplands-sourced water. The mean residence time of the water is $10.2 \mathrm{yr}$ giving a total water volume in the aquifer of $3.0 \mathrm{~km}^{3}$. The powerful upflow near the springs carries sea water from depth. $9 \%$ of the karst uplands water is discharged at the Fish Creek Springs, and the rest seeps upwards into the overlying second system.

The second system is a shallow aquifer underlying the Takaka Valley. Recharge is from sinks in the bed of the Takaka River and rainfall on the valley where the AMA is unconfined. Much of the water flows downvalley and is discharged in springs offshore (52\%), but some is discharged in the Main Spring complex (25\%) and Fish Creek Springs (23\%). The mean residence time is $1.2 \mathrm{yr}$ giving a water volume in the system of $0.4 \mathrm{~km}^{3}$.

The very different behaviours of the two systems are believed to be due to the presence of a diorite intrusion at shallow levels below the surface of the lower Takaka Val- ley. This intrusion diverts the deep water flow towards the Pupu Springs, blocking it from flowing towards the sea, and thereby separating the deep flow or system from the shallow flow or system, much of which travels over the intrusion and escapes via submarine springs.

This research has revealed two apparently paradoxical results. 1. The age of the Pupu Springs water increases with flow (in contrast to most other springs investigated elsewhere). 2. The deep system contains infiltrated sea water but does not lose (fresh) water to the sea, while the shallow system loses (fresh) water to the sea but does not gain sea water by infiltration. A buried diorite intrusion provides a good explanation for these seeming paradoxes.

Acknowledgements. The authors thank U. Morgenstern and R. van der Raaij for contributing data and insight on age dating, and Vanessa Trompetter (nee Fox) for the CFC measurements. The USGS at Reston, VA, USA (E. Busenberg, L. N. Plummer and others) are thanked for generously training Vanessa in the CFC measurement techniques. C. B. Taylor ( $\dagger$ ) is acknowledged for his excellent contributions in developing the tritium laboratory and in contributing to understanding of the Pupu Springs. We appreciate the comments of the two anonymous journal referees.

Edited by: T. Elliot

\section{References}

Bergmann, H., Sackl, B., Maloszewski P., and Stichler, W.: Hydrological investigation in a small catchment area using isotope data series, in: Proceedings of the Fifth International Symposium on Underground Water Tracing. Institute of Geology and Mineral Exploration, Athens, 255-272, 1986.

Busenberg, E. and Plummer, L. N.: Use of chlorofluorocarbons $\left(\mathrm{CCl}_{3} \mathrm{~F}\right.$ and $\left.\mathrm{CCl}_{2} \mathrm{~F}_{2}\right)$ as hydrologic tracers and age-dating tools: The alluvium and terrace system of Central Oklahoma, Water Resour. Res., 28(5), 2257-2283, 1992.

Davies-Colley, R. J. and Smith, D. G.: Optically pure waters in Waikoropupu ("Pupu") Springs, Nelson, New Zealand, New Zeal. J. Mar. Fresh., 29, 251-256, 1995.

Doyle, M. and Edgar, J.E.: There are no springs in the water balance, New Zealand Hydrological Society 1998 Symposium Proceedings, p. 27, Dunedin, 24-27 November 1998.

Edgar, J. E.: Hydrogeology of the Takaka Valley, M.Sc. Thesis, University of Canterbury, p. 303, 1998.

Elliot, T., Andrews, J. N., and Edmunds, W. M.: Hydrochemical trends, paleorecharge and groundwater ages in the fissured Chalk aquifer of the London and Berkshire Basins, UK Appl. Geochem., 14, 333-363, 1999.

Fleury, P., Bakalowicz, M., and de Marsily, G.: Submarine springs and coastal karst aquifers: A review, J. Hydrol., 339(1-2), 79-92, doi:10.1016/j.jhydrol.2007.03.009, 2007.

Ford, D. C. and Williams, P. W.: Karst Geomorphology and Hydrology, Chapman and Hall, London, 1989.

Jones, W. M.: Magnetic observations in the Onekaka-Parapara District, with some remarks on the geology of the iron-ore deposits, New Zeal. J. Sci., 21B(1), 16-30, 1939. 
Hulston, J. R., Taylor, C. B., Lyon, G. L., Stewart, M. K., and Cox, M. A.: Environmental isotopes in New Zealand hydrology, Part 2: Standards, measurement techniques and reporting of measurements for oxygen-18, deuterium and tritium in water, New Zeal. J. Sci., 24, 313-322, 1981.

IAEA: Fifth IAEA intercomparison of low-level tritium measurements in water, Report prepared by Östlund, G., Scott, E. M., and Taylor, C. B. for the Isotope Hydrology Section of the I.A.E.A., Vienna, Austria. 1995.

Maloszewski, P. and Zuber, A.: Determining the turnover time of groundwater systems with the aid of environmental tracers, 1. Models and their applicability, J. Hydrol., 57, 207-331, 1982.

Maloszewski, P., Stichler, W., Zuber, A., and Rank, D.: Identifying the flow systems in a karstic-fissured-porous aquifer, the Schneealpe, Austria, by modelling of environmental ${ }^{18} \mathrm{O}$ and ${ }^{3} \mathrm{H}$ isotopes, J. Hydrol., 256, 48-59, 2002.

Michaelis, F. B.: Physico-chemical features of Pupu Springs. New Zeal. J. Mar. Fresh., 10(1), 613-628, 1976.

Morgenstern, U. and Taylor, C. B.: Low-level tritium measurement using electrolytic enrichment and liquid scintillation counting, Proc. International Symposium on Quality Assurance for Analytical Methods in Isotope Hydrology, Vienna, Austria, 2005.

Mueller, M.: Karst hydrogeology of the Takaka Valley, Golden Bay, northwest Nelson, New Zeal. J. Geol. Geop. 34, 11-16, 1991.

Mueller, M.: Geohydrology of the Takaka Valley, Unpublished report, Tasman District Council, Richmond, N.Z., 1992.

Park, J.: On the geology of Collingwood County, Nelson, New Zealand Geological Survey report of geological exploration 20, 186-243, 1890.

Plummer, L. N. and Busenburg, E.: Chlorofluorocarbons, Chapter 15 in Environmental Tracers in Subsurface Hydrology, edited by: Cook, P. and Herczeg, A. L., Kluwer Academic Publishers, 441478, 1999.

Rapier, D.: Waikoropupu Springs - some hydrological aspects, Unpublished report, N.Z. Ministry of Works, Nelson, N.Z., 1975.

Rattenbury, M. A., Cooper, R. A., and Johnston, M. R. (Compilers): Geology of the Nelson Area. IGNS 1:250000 Geological Map 9, 1 sheet and 1-67, 1998.

Rank, D., Völkl, G., Maloszewski, P., and Stichler, W.: Flow dynamics in an alpine karst massif studied by means of environmental isotopes. Isotope Techniques in Water Resources Development 1991, IAEA Symposium 319, March 1991, Vienna, 327343, 1992.

Rosen, M. R., Cameron, S. G., Taylor, C. B., and Reeves, R. R.: New Zealand guidelines for the collection of groundwater samples for chemical and isotopic analyses, I.G.N.S. Science Report 99/9, 1-81, 1999.
Siegenthaler, U., Schotterer, U., and Muller, I.: Isotopic and chemical investigations of springs from different karst zones in the Swiss Jura, In Isotope Hydrology 1983, 153-172, Vienna, IAEA, 1984.

Stewart, M. K. and Downes, C. J.: Isotope hydrology of Waikoropupu Springs, New Zealand, Isotope Studies of Hydrologic Procesess, NIU Press, DeKalb, IL., 15-23, 1981.

Stewart, M. K. and Morgenstern, U.: Age and source of groundwater from isotope tracers, in: Groundwaters of New Zealand, edited by: Rosen, M. R. and White, P. A., New Zealand Hydrological Society Inc., Wellington., 161-183, 2001.

Stewart, M. K. and Taylor, C. B.: Environmental isotopes in New Zealand hydrology, 1. Introduction: The role of oxygen-18, deuterium and tritium in hydrology, New Zeal. J. Sci., 24, 295-311, 1981.

Stewart, M. K. and Williams, P. W.: Environmental isotopes in New Zealand hydrology, 3. Isotope hydrology of Waikoropupu Springs and Takaka River, northwest Nelson, New Zeal. J. Sci., 24, 323-337, 1981.

Stewart, M. K., Cox, M. A., James, M. R., and Lyon, G. L.: Deuterium in New Zealand rivers and streams, I.N.S. Science Report (INS-R-20), 1-32, 1983.

Stewart, M. K., Mehlhorn, J., and Elliott, S.: Hydrometric and natural tracer $\left({ }^{18} \mathrm{O}\right.$, silica, ${ }^{3} \mathrm{H}$ and $\left.\mathrm{SF}_{6}\right)$ evidence for a dominant groundwater contribution to Pukemanga Stream, New Zealand, Hydrol. Process., 21, 3340-3356, doi: 10.1002/hyp.6557, 2007.

Taylor, C. B.: The relationship between electrolytic deuterium and tritium separation factors, and attainment of improved accuracy in radiometric low-level tritium measurement, J. Appl. Rad. Isotopes, 45(2), 683-692, 1994.

Taylor, C. B.: Contributing sources to Waikoropupu Springs, Takaka, NW Nelson: a new assessment, New Zealand Hydrological Society 2001 Symposium Proceedings, 38-39, Palmerston North, 20-23 November 2001.

Thomas, Joseph: Groundwater resources of the Tasman Region. In Groundwaters of New Zealand, edited by: Rosen, M. R. and White, P. A., New Zealand Hydrological Society Inc., Wellington., 411-425, 2001.

Williams, P. W.: Hydrology of the Waikoropupu Springs: a major tidal karst resurgence in northwest Nelson (New Zealand), J. Hydrol., 35, 73-92, 1977.

Williams, P. W.: Karst systems, Chapter 31 in: Freshwaters of New Zealand, edited by: Harding, J. S., Mosley, M. P., Pearson, C. P., and Sorrell, B. K., New Zeal. Hyd. Soc. and New Zeal. Lim. Soc., Christchurch, New Zealand, 2004.

Williams, P. W.: Limestone Country, Te Ara - the Encyclopedia of New Zealand, available at: http://www.teara.govt.nz/TheBush/ Landscapes/LimestoneCountry/en, 2007. 